Volume 13, Issue 2 (Summer 2021)

\title{
Jan van Goyen: Virtuoso, Innovator, and Market Leader
}

Eric Jan Sluijter, Nicolette Sluijter-Seijffert (translator)

Recommended Citation:

Eric Jan Sluijter, Nicolette Sluijter-Seijffert (translator), "Jan van Goyen: Virtuoso, Innovator, and Market Leader," Journal of Historians of Netherlandish Art 13:2 (Summer 2021)

DOI: $10.5092 /$ jhna.13.2.4

Available at https://ihna.org/articles/van-goven-virtuoso-innovator-market-leader/

Published by Historians of Netherlandish Art: https://hnanews.org/

Republication Guidelines: https://jhna.org/republication-guidelines/

Note: This PDF is provided for reference purposes and does not contain all the

functionality and features of the online publication. Illustrations follow the text. This PDF provides paragraph numbers as well as page numbers for citation purposes.

ISSN: 1949-9833 


\section{Jan van Goyen: Virtuoso, Innovator, and Market Leader}

Eric Jan Sluijter, Nicolette Sluijter-Seijffert (translator)

This article is a translation from the original Dutch, which first appeared in the catalogue for the exhibition Jan van Goyen (Stedelijk Museum De Lakenhal, Leiden, 1996). The essay examines the "strategies" regarding style, subject matter, technique, and price level that Jan van Goyen appears to have used to position himself in the art market. In particular, it discusses the radical change in style and the continuous innovations that Van Goyen introduced into his landscapes as he became a market leader. The Postscript offers insight into the origin and aim of the essay and refers to relevant information that emerged after the initial publication date.

\section{AUTHOR'S NOTE, 2021}

1 At some places in the present translation, I have referred in footnotes between curly brackets \{braces\} to other more recent publications on topics discussed in the article. In the article itself, I have added a few lines prompted by more recent information, also identified by curly brackets.

\section{A Renowned Landscape Painter}

2 In the first half of the seventeenth century, Jan van Goyen's contemporary Constantijn Huygens was the only author to record his opinion on Dutch landscape painting. The words that he committed to paper, in the autobiography of his youth, make clear that Huygens considered the art of landscape painting a miraculous phenomenon. His immense admiration for Rubens and his excessive praise for the young Rembrandt did not interfere with a profound appreciation for contemporary landscape painters: "One could even say that nothing is lacking in the work of those clever men except for the warmth of the sun or the movement caused by a gentle breeze." ${ }^{1}$

According to Huygens, "the harvest of landscape painters in our Netherlands is so vast and so renowned that one would need to write a whole booklet to mention them one by one." Thus, if we are to believe Huygens, landscape painting had achieved broad fame by the late 1620s. This was indeed a decade in which the production of landscape paintings increased hugely, although the apogee-at least where quantity is concerned - was still to come. Of the five landscape painters whom Huygens mentioned by name, he praised in particular the Antwerp painter Jan Wildens, a friend of Rubens, as well as Esias van de Velde, based in The Hague. However, he began by stating: "as for the rest, their own reputation should plead for them, and that of Van Poelenburch, Van Wtenbrouck, Van Goyen, and others is truly quite extraordinary." 
The most remarkable aspect of this statement is Huygens's mention of such opposites as Cornelis van Poelenburch (fig. 1) and Jan van Goyen (fig. 2) in the same breath. We might expect something different from this courtier, poet, and homo universalis, who could boast a consummate humanistic education. With these words of praise about landscape painters, he does not place any higher value on the painters of idyllic, Italianate landscapes with Roman ruins and small biblical, mythological, or pastoral scenes than the artists who painted the Dutch landscape and took inspiration from the surroundings of Leiden, Haarlem, and The Hague: landscapes with farmhouses, villages, waterways, pastures and dunes, where peasants and travelers proceed on their way (in addition to Van Goyen, Esaias van de Velde also produced work in this vein; see fig. 3).

5 Not only did Huygens place painters who made different types of landscape on a par with one another, these artists also worked in different painting techniques, producing pictures that differed greatly in price. Cornelis van Poelenburch's landscapes were costly paintings executed with exquisitely detailed and refined technique. Esaias van de Velde, on the other hand-and his pupil Van Goyen would emulate him in the extreme-developed a rapid painting technique that enabled him to produce relatively cheap pictures at a fast pace. Apparently, Huygens appreciated both landscape types. ${ }^{3}$

A comparable opinion, more strongly put, is found in an earlier paragraph of Huygens's text; here he says that he can hardly name Hendrik Vroom in the same breath as Jan Porcellis. ${ }^{4}$ In this case, we see how, in Huygens's opinion, an artist who mainly painted costly, finely rendered works - paintings with many details, in which imposing warships or East Indian merchantmen were depicted with great accuracy - had been surpassed by an artist who made inexpensive, rapidly painted, unpretentious images of anonymous fishing boats and other inland vessels sailing the Dutch waters (fig. 4).

In art-historical literature, it has often been maintained that paintings of Dutch landscapes were valued less than those of foreign scenes and that these cheaper pictures were meant for a less sophisticated public. Many twentieth-century authors asserted that Van Goyen was not much appreciated by his contemporaries and was even so badly paid for his paintings that he could make a living only by working at another occupation. ${ }^{6}$ If it were indeed true, however, that people "wanted to pay much less for a native subject one could see outside every day," as Henri van de Waal stated, ${ }^{7}$ the question remains why these images were painted in such incredible numbers-not only by Van Goyen and such colleagues as Salomon van Ruysdael, but also by Van Goyen's numerous followers, all of whom apparently considered them profitable. This was not a matter of an inner artistic need, contrary to the opinion of many past art historians. Scholars in the nineteenth and twentieth centuries were probably misled by the relatively low prices of Van Goyen's works. They were eager to assume that Van Goyen was undervalued by his contemporaries and that the depiction of the commonplace and the familiar did not receive the recognition it deserved. The words of someone like Constantijn Huygens, who had called Van Goyen a renowned master as early as 1631, point us in another direction. 

praises Leiden's greatness in the past and the present by exhaustively describing its history, government, and institutions. Further, Leiden's famous "sons" are honored with short biographies. Orlers chose only two groups of people to represent these illustrious citizensscholars, and painters - and he paid a great deal of attention to the latter. Apparently, he saw them as contributing greatly to the city's fame. For the painters of the sixteenth century, Orlers made use of biographies written by Karel van Mander, with whom he had been friendly in his younger years. For the living painters he added to the second edition of 1641, he had to draw from his own assessment and knowledge. To that end, he addresses a limited selection of seven artists: David Bailly, Joris van Schoten, Jan van Goyen, Pieter de Neyn, Rembrandt van Rijn, Jan Lievens, and Gerrit Dou. The inclusion of a biography in such a prestigious book would have given these painters exceptionally high status in the city's society; it must have contributed enormously to their self-esteem and self-confidence.

Orlers's writing about these artists shows no hierarchic differentiation between painters of histories, landscapes, portraits, or contemporary life. They all belong to the category of "famous and excellent Painters, whose worthiness and deserved glory can easily be proven by their immensely beautiful and priceless Paintings, which can be found inside as well as outside the city: with these they deserve and are worthy of being recorded and registered in all books of Laudation and History."

10 Orlers dedicates more than one page to Jan van Goyen-equal to Gerrit Dou, and many more lines than he devotes to Rembrandt. Remarkably, he pays detailed attention to Van Goyen's apprenticeship with six(!) different masters, probably to give an example of the intensive schooling necessary to become a renowned master in painting. He characterizes Van Goyen as one of the "most artful landscape painters ... who in our time and age are famous and well known." He also explicitly praises Van Goyen's capability in painting figures ("and the pleasantness of the figures therein"). ${ }^{10}$ Lastly, he adds that "of this the numerous paintings that are highly valued by all liefhebbers can bear witness." Thus, Orlers also emphasizes that liefhebbers (lovers of art, connoisseurs) show great esteem for Van Goyen's works. How can this be reconciled with the low prices of Van Goyen's paintings?

\section{Position in the Art Market}

11 As noted above, Van Goyen used a rapid technique that was developed concurrently by Esaias van de Velde and Jan Porcellis around 1615-during the period of Van Goyen's apprenticeship and early independence. This manner of painting, in which only a few colors were applied with loose brushstrokes in one layer onto a thin ground, made a large production possible and lowered the cost of materials as well. ${ }^{11}$ Half a century later (1678), Van Hoogstraten refers to this phenomenon by saying that, although in the beginning of the century the walls in Holland were not as crammed with paintings as they are in his time, the practice daily became more and more fashionable, "which strongly impelled some painters to take to rapid painting, yes even to produce one piece a day, whether small or large." In this way, they "sought both profit and 
fame." ${ }^{12}$ Van Hoogstraten here alludes to such painters as Porcellis and Van Goyen, judging by the anecdote he tells immediately afterward of a painting contest between Van Goyen, Porcellis, and Knibbergen. We cannot establish with certainty if it was usual for these artists to make one painting, "whether small or large," in one day, but we do know that in 1615 Porcellis signed a contract with an art dealer stating that he would deliver two paintings every week. ${ }^{13}$

John Michael Montias was the first to demonstrate convincingly that, in addition to radical specialization, this "process innovation" was an efficient way to economize on the cost of labor in a period wherein - as Van Hoogstraten makes clear-the demand for paintings as well as the competition among artists was growing explosively. ${ }^{14}$ From the 1620 s on, the young painter thus had the choice between this rapid, inexpensive method of production that required a "loose" manner of painting, or the more traditional "neat" (and therefore more expensive) painting technique. ${ }^{15}$ Van Goyen chose-only after some time, as we will see-the first method and would develop it to the extreme, while other painters of his generation did the same in different genres. These include such artists as Dirck Hals in paintings of contemporary life or Pieter Claesz. in still lifes. On the other hand, such landscape painters as Cornelis van Poelenburch (figs. 1, 11) and Alexander Keirincx (fig. 5) chose the second method, as did Balthasar van der Ast in still lifes (to name a few); Van Goyen's younger fellow townsman, Gerrit Dou, explored the "neat" manner to its fullest potential.

Once artists no longer worked on commission and their pictures were sold via their own shops or through art dealers, auctions, or lotteries, the latter method would have brought more risks. Using this time-consuming working method would have made it more aggravating when a painting was not sold for a long time: one needed to have some certainty about clients who could be trusted to buy the painting one had spent so much time on. In the case of Gerrit Dou, we know that even in his early period he could rely on several collectors who were more than eager to buy his works, and in one case paid him a yearly stipend for the right of first refusal. ${ }^{16} \mathrm{~A}$ painter like this mainly worked for a relatively small group of liefhebbers, who every once in a while visited the artist's workshop. The works of such painters-this is also true of Cornelis van Poelenburch - therefore often ended up with a few rich collectors who, as Maecenas, frequently bought their paintings. ${ }^{17}$

There was less risk in using a rapid production method, and the number of painters who fabricated cheaper works must therefore have been large. For most of them, making paintings in the manner of better-known masters would have been the safest way to guarantee a sufficient income. Those who had above-average capacities and ambition, however, sought to gain a place in the art market by becoming known for a recognizable type of painting of good quality. ${ }^{18}$ Some of them succeeded well by combining technical virtuosity and exceptional inventiveness in developing new types of painting that were received favorably. Jan van Goyen definitely belonged among those few artists and, given the large number of followers throughout his career, could be called a trendsetter and market leader. ${ }^{19}$ In a relatively short period of time, he made a name for himself and earned good money. 
Van Goyen was intensely involved with speculating in real estate. But that alone is not evidence that he needed other activities to support himself, as has generally been suggested. ${ }^{20}$ Rather, it meant that he soon earned enough money to invest in order to increase his capital; he was an eager speculator, like many of his contemporaries. From 1625 on, he bought houses and pleasure gardens for hefty sums, sometimes with cash deposits, and sold them as soon as possible. After moving to The Hague, he bought plots of land for the construction of houses in a time when the city was rapidly expanding. ${ }^{21}$ The poor outcome of this enterprise suggests that his speculative spirit was stronger than his insight or luck in this field. ${ }^{22}$ Nonetheless, although he had large debts at his death, he still owned six houses in The Hague, which sold for 15,670 guilders in total. ${ }^{23}$

Apart from his speculation in property and his art dealing, Van Goyen's large production of paintings gave him a sufficient and reasonably secure income during most of his life. It seems that when times were good-as in the years 1636 to 1639, when he was busy building housesthe number of his paintings dropped drastically. When his debts increased because of his less lucrative dealings as a speculator and contractor, he augmented his painting production dramatically (1641-1647). ${ }^{24}$ This recalls a poem by Jacob Cats in which a painter, a merchant, and a poet compete for the hand of a young beauty. In recommending himself and his craft, the painter asserts that he can do business like the merchant, but his art involves him in no risks. When the merchant loses his merchandise-by a shipwreck or some other disaster-he has nothing left, but the painter declares that if something like that happened to him, he would still have his art:

The Art, that noble thing, will not abandon me, Even had I to roam the streets without proper clothes; Even were I fleeing from war, running from fire, I would still own my very best asset.

Contrasting the advantages of painting against the arguments of the poet, this same painter states that he can earn good money with his art: "And that is very useful if one has a home and a family." ${ }^{25}$

17 A painter's earnings could vary immensely, however. In a 1642 request to the City Council, painters in Haarlem distinguished between "ordinary painters" (gemeene schilders) and "extraordinary masters" (extraordinare meesters); the latter were, of course, the artists who signed the petition: Frans Pietersz. de Grebber, Frans Hals, Pieter de Molijn, and Salomon van Ruysdael. ${ }^{26}$ For the "ordinary" painters, the makers of "paintings of low quality" (slechte schilderijen), it was not easy to keep afloat financially. Often they worked for art dealers who specialized in the cheapest market segment, mostly selling their paintings anonymously. ${ }^{27}$ These artists were probably the suppliers of the numerous anonymous works we find in seventeenthcentury inventories, paintings whose makers were not identified when an inventory was drawn up and whose price estimates were very low (usually less than five guilders). ${ }^{28}$ The other end of the spectrum included the "extraordinary masters," those painters who had made a name for themselves and whose works were much appreciated, ranging from history and genre painters to 
landscape painters such as Pieter de Molijn and Salomon van Ruysdael. They mostly sold their works from their own workshops, and the authors of inventories frequently identified their paintings by name. ${ }^{29}$ Jan van Goyen belonged at the top of this category.

\section{A Wide Popularity}

18 Inventories that include paintings collected during Van Goyen's lifetime reveal that no other Dutch painter was as generally represented as Jan van Goyen. ${ }^{30}$ Drawing conclusions from the presence of paintings in inventories is a hazardous undertaking, because the existence and survival of household inventories containing descriptions of paintings depends on all kinds of accidental factors. Moreover, the inventories that have been retrieved and studied (by such researchers as Abraham Bredius, John Michael Montias, Willemijn Fock, and Pieter Biesboer) were assembled in different ways. ${ }^{31}$ Nevertheless, they do offer some remarkable insights.

In the Leiden inventories selected by Willemijn Fock, the name Van Goyen appears most frequently by far, roughly twice as often as the next-most-mentioned painter. ${ }^{32}$ In the Delft inventories researched by Montias, Van Goyen comes in ninth place, but he is first among artists from outside Delft (the second non-Delft painter follows at a great distance-in seventeenth place). ${ }^{33}$ In the Amsterdam inventories also collected by Montias, Van Goyen appears among the top ten, ${ }^{34}$ while in the Haarlem inventories researched by Pieter Biesboer he places third. This third place is a provisional estimate by Pieter Biesboer. \{Van Goyen is indeed in third place, with no fewer than seventy-nine paintings; his numbers are the highest of the landscape painters, followed by Pieter de Molijn with seventy paintings and Cornelis Decker with sixty-two. See Pieter Biesboer, Collection of Paintings in Haarlem, 34. ${ }^{35}$ Regrettably, not much is known about The Hague, but one can expect him to be at the top there as well.

20 This widespread popularity is confirmed by the fact that Van Goyen's works are the most numerous among the large number of landscape paintings in the inventories with price estimates assembled by Alan Chong, ${ }^{36}$ and that Van Goyen's paintings are also those recorded most often in Bredius' Künstler-Inventare. Moreover, it is obvious that his works, in contrast to those of expensive painters such as Dou and Poelenburch, were not concentrated within a limited number of liefhebbers' collections but that they enjoyed a wide distribution. ${ }^{37}$ Nonetheless, Van Goyen's landscapes had some ardent collectors-like the medical doctor Gabriël Ypelaer, who had among his fifty-seven paintings no fewer than twelve works by Van Goyen, and the bookseller Jan Jansz. van Rhijn, who owned ten paintings by Van Goyen (altogether he had 166 paintings); both were Leiden residents. ${ }^{38}$ Indeed, larger numbers of Van Goyen's work are found most often in Leiden inventories, as in the enormous collection of Henric Bugge van Ring (237 paintings!), which lists seven paintings by Van Goyen. ${ }^{39}$ The medical doctor Gerard van Hoogeveen had, among his 163 paintings, six by Van Goyen, plus four copies after his works, ${ }^{40}$ and in the lavish estate of the banker Jean François Tortarolis (173 paintings) we also find six works by Van Goyen. ${ }^{41}$ Both the goldsmith Jan van Griecken as well as the widow Sara de Witte owned six of his paintings, too, and the book printer Jean le Maire had five. ${ }^{42}$ 
Remarkably, as early as 1629 , we encounter five paintings by Van Goyen in an inventory of the Amsterdam landscape painter Barent Theunisz Drent, about whom little is known. (This is also the earliest Amsterdam inventory in which a work by Rembrandt, a little tronie, is recorded). ${ }^{43}$ The collection of the lawyer Johan Bardoel in Haarlem included five works by Van Goyen along with two copies (a pair of pendants), ${ }^{44}$ and even in Utrecht we find an ardent collector of Van Goyen's art in the person of Nicolaes Meyer, in whose large collections were nine of Van Goyen's works. ${ }^{45}$ Five works, and one landscape by Knibbergen with figures by Van Goyen, are recorded in the inventory of Cornelis Bosman of The Hague, a prosecutor for the Court of Holland.$^{46}$ Lastly, the wealthy Amsterdammer Jan van de Cappelle, successful as both manufacturer and a painter, must have been a great admirer: he owned no fewer than ten paintings and 417 drawings by Van Goyen! ${ }^{47}$ That Van de Cappelle favored "tonal" works by painters of the older generation is evident from the fact that he possessed no fewer than nineteen paintings by Porcellis, nine pieces by Simon de Vlieger, and also nine by Esaias van de Velde. ${ }^{48}$

The large number of records of Van Goyen's work in widely diverse inventories not only shows that his paintings were much appreciated in different Dutch cities but also that they were easily recognized by the people who drew up the inventories. Apparently, it must have been considered important to mention his name explicitly. Other painters' names were, in most cases, only recorded when their works appeared in inventories of fellow townsmen; this implies that their work was either sold only in their own city or was unrecognized outside that city by the authors of these notarial documents. Van Goyen's work, however, was clearly so well known that his paintings are identified even in Amsterdam or Haarlem inventories that contain few other attributed pieces. The Haarlem inventory of Michiel van Barrelebos (1664), with twenty-five paintings of which only one is identified, as "a large piece by Van Goyen," is just one example. The same is true for the inventory of Bregitta Screvelius (1657), also in Haarlem, which includes only anonymous works, except for "a shepherd and a shepherdess . . by Jan van Goyen from Leyden" and "a fat [dick] tronie of the famous rembrant van Leyden." ${ }^{49}$ In the inventory of the Haarlemer Pieter Bruyningh (1664), with fifty paintings, only three painters are named, and one of them is Van Goyen; the other two are Haarlem artists (Dirck Hals and Pieter de Molijn). $\frac{50}{}$ Even among the 142 pieces in the possession of the Amsterdam patrician Floris Soop (1657), only four artists' names are mentioned-and again, one of them is Jan van Goyen. ${ }^{51}$

23 Inventories like these, which specify only a few names of painters, would generally not have contained collections of outstanding quality. Van Goyen's paintings, however, are found similarly in the possession of people with neither great wealth nor exceptional connoisseurship as well as people who owned uncommonly fine paintings collections assembled with obvious expertise..$^{52}$ The Amsterdam art dealer Johannes de Renialme, who worked primarily within the top of the collectors' market, had paintings by Van Goyen in his inventories of 1640 and $1657 .{ }^{53}$ In his stock, they belonged to the category of inexpensive works of about the same value as paintings by, for example, Jan Miense Molenaer, Adriaen Brouwer, and Leonard Bramer. But it should be noted that, for instance, tronies by Rembrandt, Dou, and Lievens (and landscapes by Lievens) - all "rapidly" produced works by "expensive" painters-were also assigned the same low-priced category, or even a lower-priced one..$^{54}$ 
It is also remarkable that copies after Van Goyen were soon recognized as such. Copies seem to have entered the market in large numbers. In one of the few auctions in this period whose contents we know, the 1647 auction in The Hague, thirteen copies after Van Goyen were on sale ${ }^{55}$-and the compiler apparently considered their status as copies worth acknowledging. This means that great value was attached to autograph works by Van Goyen. It also means that even mentioning Van Goyen's name set a painting apart from anonymous works (of which there must have been many that were also copies). In a Delft inventory from 1638, compiled when it was not yet usual to cite many artists' names in inventories, a copy as well as a "principal" (principael) by Van Goyen are recorded. ${ }^{56}$ In later inventories, we encounter this many times. I have already referred to the four copies (besides seven originals) in the impressive collection of the Leiden medical doctor Gerard van Hoogeveen and the two copies with Johan Bardoel in Haarlem. ${ }^{57}$ Particularly interesting is a copy in a Delft inventory from 1650 that is estimated at an even higher value than paintings by Palamedes or Molijn in the same collection (seven guilders and five pennies). ${ }^{58}$

The value of the autograph status attached to Van Goyen's paintings is made evident from the difference between the price of copies and that of originals. De Marchi and Van Miegroet calculated that in the seventeenth century an original was on average evaluated as two to three times higher in worth than a copy after the same master, and they assumed that these differences were the norm..$^{59}$ In one case, we know the prices of originals as well as of copies after Van Goyen: the aforementioned massive auction in The Hague (1647), in which Van Goyen himself was involved. ${ }^{60}$ By examining the average prices of all 850 original paintings in this auction (9.3 guilders) and the sixty-eight copies (4.13 guilders), ${ }^{61}$ we can infer that the difference noted above is indeed correct: the originals were two and a quarter times more expensive than the copies. If we count only Van Goyen's originals and the copies after his work, however, we see a remarkable result: the twenty-three principals by him for which the hammer prices are noted yielded no less than six times as much as the eleven copies (18.6 guilders, compared to 2.9). ${ }^{62}$ It would therefore have been important for a buyer to be able to distinguish between a genuine Van Goyen and the many copies of his work.

The fact that Van Goyen inscribed his works with his monogram and a date more frequently than any other painter seems to indicate that he meant this as a guarantee of authenticity, especially given the extensive imitation of his works and their wide distribution. Connoisseurs would also have paid attention to the date, since Van Goyen was a painter who changed his style from time to time and introduced a different type of landscape once the previous type had been imitated too often. In a Leiden inventory noting seven paintings by Van Goyen, one was described as "done in the year $1627 ;$ " ${ }^{63}$ this seems to indicate that the specific period was considered a factor in determining the work's value. ${ }^{64}$

\section{Price Level}

Although the prices in this Hague auction were not very high, we can still conclude that the average price of Van Goyen's original works was twice as high as the average of the other 
paintings sold in the auction as autograph works. We also note that paintings by such followers as Johannes Schoef and Anthony van der Croos fetched, on average, about half the price of an original painting by Van Goyen. Works by Esaias van de Velde, Gerard Houckgeest, Abraham van Beyeren, and Pieter de Molijn reached the level of Van Goyen's. As expected, paintings by Cornelis van Poelenburch, Gerard ter Borch, and above all Jan Davidsz. de Heem (one hundred guilders) realized the highest prices. These were all renowned painters with "neat," detailed styles.

An examination of Leiden inventories from before 1660 reveals that, of the works by Van Goyen that have valuations, the average result is eighteen guilders, with highs of twenty-six and thirtythree guilders \{plus one peak: a painting that was valued at one hundred guilders\} ${ }^{65}$ Willemijn Fock has already concluded that "the often-expressed opinion that Van Goyen was paid so badly for his works compared to other artists ... appears absolutely untrue." Van Goyen's works were appraised the highest of all those by painters whom one could call "rapid painters." Unfortunately, the number of estimated pieces in these Leiden inventories is low (only ten pieces before 1660). $\left\{{ }^{66}\right\}$ In Leiden and other cities, however, I was able to track down in inventories (together with the Hague auction) a total of forty-six paintings with a valuation price-or the price yielded at auction-before 1660. Altogether, they have an average price of 19.2 guilders. \{The painting valued at one hundred guilders was not included in the calculation. ${ }^{67}$

The highest valuations were \{apart from the one hundred guilders for "a large landscape with inns" in the 1650 inventory of the merchant Jean le Pla in Leiden, valued by the expert Hendrick Uylenburg\} a landscape in the 1653 inventory of the Haarlem merchant Dirk Smuijser at fiftyfour guilders, and a work in the inventory of the wine merchant Jan Dingman (1649), also in Haarlem, at thirty-five guilders. Also high was the price for "a principal of Van Goyen, The Hague," at thirty-two guilders and five pennies, in the auction in The Hague in 1647 (three more works by his hand sold there for thirty to thirty-two guilders) and the estimate of thirty-three guilders for a large landscape in a 1652 inventory of a Leiden draper. ${ }^{68}$ The Van Goyen in de Renialme's huge stock, appraised in 1657 by the experts Marten Kretzer and Adam Camerarius, was evaluated at forty-eight guilders. As for Amsterdam inventories between 1650 and 1679, Montias found the rather low average of 12.3 guilders (based on seven evaluated pictures) \{but if one figures in the evaluations of the seven pre-1660 Amsterdam paintings in the Montias Database, the average value is as much as 24.4 guilders $\}{ }^{69}$ We have to take into account that there was a strong fall in the prices of Van Goyen's work after $1660 .{ }^{70}$ Nevertheless, Van Goyen leaves Jan Miense Molenaer and the still-life painter Elias Vonck (who were both among the most popular painters in these Amsterdam inventories that Montias researched) far behind with respect to the price level.

30 Naturally, the valuations of paintings in inventories do not reflect the sums paid when the paintings were bought firsthand. We do not have information on such prices, but the values of paintings advertised in lotteries might represent the original or slightly inflated prices. They are considerably higher than the inventory valuations. The preserved poster of a lottery in Leiden of around 1640 shows eight works by Van Goyen; they range from seventy-eight guilders for "a large piece," to sixty-six guilders for "Two Ovals," to fifteen guilders for "a Wagon," 
average of 39.25 guilders. As is always the case, the differences in price would have been determined partly by the size of the painting (and therefore also by the costs of material and labor-it took more time to make them). Landscapes formed the majority of the works in this lottery, making up two-thirds of all the paintings offered. Apart from a work by Pauwels Hillegaert and "a five senses" by De Grebber, ${ }^{72}$ all the works by Pieter de Molijn were, on average, priced higher than those by Van Goyen (whose prices ranged from eighty-five to twenty-one guilders), whereas the works by all other landscape painters, such as Van den Bundel and Pieter de Neyn, and followers of Van Goyen like Maerten Fransz. Van der Hulst, Jan Coelenbier, and even Philips Wouwerman and Moyses van Uyttenbroeck, were cheaper, as were still-lifes by Pieter Claesz and Adriaen van Ostade.

31 Two somewhat earlier lotteries in Haarlem show a similar result: in 1634 "a large round painting with an ebony frame" by Van Goyen was raffled off for seventy-six guilders. Explicitly described as "large," it was the third-most expensive painting in the lottery; however, this lottery also contained a much less pricey work by Van Goyen of twenty guilders. ${ }^{73}$ The highest-priced works in this lottery were a "five senses" by Dirck Hals (104 guilders) and a "large round painting" by Pieter de Molijn (ninety-six guilders). We find much lower-priced works by these painters, as well (the prices of the other works by Dirck Hals vary between eighteen and thirty-six guilders). Among the painters in this lottery whose works were cheaper than those by Van Goyen are Willem Claesz. Heda, Herman Saftleven, Leonard Bramer, Salomon van Ruysdael, Adriaan van Ostade, Frans Hals, and Judith Leyster.

32 In a lottery in Haarlem in 1636, in which the paintings were appraised by Salomon van Ruysdael, Jan van de Velde, and Cornelis van Kittesteyn, the three works by Van Goyen were estimated at fifty-two, fifty, and forty-eight guilders. ${ }^{74}$ This time the history paintings by Pieter de Grebber were valued much higher, but "two hermits" by the same master were estimated at the same price as one work by Van Goyen; probably they were small, rapidly painted works. Also much more expensive were paintings by Christiaen van Couwenbergh, Moyses van Wtenbrouck, and Roelant Savery, while large pieces by Pieter de Molijn, a work by Porcellis, three landscapes by Salomon van Ruysdael, and a company by Jacob Duck were priced higher, too. On the other hand, work by Heda was priced about the same as that of Van Goyen, while small history pieces by Jacob de Wet, tronies and banquets by Hendrik Pot, and landscapes by Esaias van de Velde were valued lower.

The above-mentioned prices offer a different view of the financial value of Van Goyen's works on the contemporary art market than the valuations in the inventories. If we determine the average price of the thirteen paintings in the lotteries together with the two works in De Renialme's shop, we even come to an average price of forty-four guilders, more than twice the average of valuations in the inventories and the proceeds at auction.

To conclude, Van Goyen enjoyed a strong reputation-including outside Leiden and The Hague - and the distribution of his paintings must have been widespread. Also, his work was highly appreciated both by real liefhebbers and people who just wanted a few good paintings on their walls. ${ }^{75}$ Orlers's statement that Van Goyen was considered one of the "most artful" 
(constichste) landscape painters of the century, whose works "were esteemed highly by all liefhebbers," does not seem to be exaggerated. We should take into account that he could produce at least two paintings a week-and perhaps even one each day-for which he could receive between twenty and forty guilders (sometimes more for large and/or more elaborate paintings; sometimes less for small, very sketchy works). His level of income from paintings therefore would not have differed much from that of one of the most "expensive" seventeenthcentury painters: his famous fellow townsman Gerrit Dou. ${ }^{76}$ One can well imagine that Dou's extremely detailed and meticulously painted genre pieces, carefully built up in many paint layers, for which he asked between three hundred and one thousand guilders, woulddepending on the number of figures and wealth of objects-indeed take ten to thirty times as much as a "wet-into-wet" landscape by Van Goyen. As noted above, Dou's quickly painted tronies were priced similarly to works by Van Goyen. ${ }^{77}$ Dou's usual time-consuming way of working is evident from Sandrart's (probably somewhat exaggerated) story that he visited Dou's workshop and praised him for, among other things, the enormous accuracy with which he had depicted a broomstick. Dou replied that the broomstick still needed at least three more days of work.

As for the landscape painters, we can only guess how much time Cornelis van Poelenburch, the contemporary of Van Goyen whose works were the most expensive in this category, spent on making a painting. To assume that he must have worked three to five times as long on one piece, however, does not seem overstated (exceptionally refined figures always played an important role in his works). Comparing the prices, we can see that, in inventories before 1650, the valuations of Poelenburch's works were on average twice as high as those of Van Goyen, and as much as five times as high in inventories between 1650 and 1675. It is important to note, however, that in this later period, especially after Van Goyen's death in 1656, his works went out of fashion rapidly, whereas the value of Poelenburch's paintings kept rising. ${ }^{78}$ During their lifetimes, Van Goyen and Poelenburch might well have calculated similar sums for a day's work, the normal method Dutch painters used to set the value of their paintings. The price level of a day's work depended on their reputation. $\left\{{ }^{79}\right\}$

Van Goyen twice received a prestigious commission commanding a princely sum in payment. In 1651, the court paid him no less than three hundred guilders for a painting of "one of His Highness's country houses situated in Burgundy." Unfortunately, no information survives about this painting; it was probably destined for Honselaarsdijk Palace ${ }^{80}$ In the same year, The Hague City Council commissioned a view of The Hague (fig. 6), ${ }^{81}$ for which they paid 650 guilders. At first sight, these prices seem outrageously high compared to what Van Goyen usually charged. They have always been referred to with astonishment. ${ }^{82}$ But the view of The Hague measures more than four and a half meters wide, and Van Goyen exchanged his usual method of working for a more refined and detailed style. The painting, one realizes, must have taken him more than ten times as long as he usually spent even on a substantial painting. Moreover, apart from its size and many fine details, such a specific commission would not have relied on existing sketches or his memory. He would have made new topographical drawings, adding to his investment of time. 
This painting clearly shows that Van Goyen made a stylistic choice. He chose the "neat" style for specific occasions, probably when the price had been set in advance. Similarly, the two-and-ahalf-meter-wide view of the river Vliet near Leiden, featuring the country seat Roucoop \{more recently identified instead as Oostbos\}, was undoubtedly produced on commission (fig. 7).$^{83}$ Given their format and careful finish, a number of other paintings must have been painted on commission as well-for example, the four exceptionally large views with town profiles, roughly one-and-a-half by two meters each, all painted in 1641. Two of them are views of Dordrecht and Haarlem, probably painted as pendants; their dimensions are exactly the same $(161.5 \times 254 \mathrm{~cm})$, and their compositions perfectly match one another. ${ }^{84}$ Someone must have wanted prestigious paintings of the two oldest cities of Holland. Dordrecht and Haarlem had the oldest city rights, a position still considered of great importance. In the hierarchy of cities, they were officially numbers one and two. This was the order in which the representatives of the cities always spoke in the meetings of the States of Holland. The painting of the Valkhof in Nijmegen, only a few centimeters shorter in height, was possibly a commission from that city (fig. 8). The large canvas with the view of Rhenen is somewhat smaller but might have been cropped (143.5 $\mathrm{x}$ $221.5 \mathrm{~cm}) .{ }^{85}$ One might wonder whether these two, together with the paintings of Dordrecht and Haarlem, were originally meant as a series of four-but their compositions make this hypothesis seem implausible. ${ }^{86}$

38 Van Goyen's large production and long career explain, in part, why the prices of his paintings did not rise above a certain level during his lifetime, notwithstanding his great fame; numerous works by him were always available on the art market. When works of a famous painter are rare, this affects prices. ${ }^{87}$ In understanding the relatively high valuations of works by Jan Porcellis, the other highly acclaimed master in the "rapid manner," we should not forget that their prices are known from inventories made after he died (1632), when his works had become scarce. ${ }^{88}$ As Van Mander notes in his biography of Joachim Beuckelaer, after the death of a master the value of his paintings could rise rapidly. ${ }^{89}$ This certainly happened after Porcellis's death.

After Van Goyen's death, by contrast, a similar increase in value did not take place. Apart from the huge number of his paintings on the market, quickly painted "monochrome" works went totally out of fashion. Paintings by Porcellis were fetching lower prices after 1660 as well. Later in the century, the valuations of their works became even lower, and the inventories mention them less frequently. This does not mean that their paintings disappeared without a trace but that their presence in the more prestigious collections dwindled, or they were not deemed important enough to mention. It may even mean that their names were not familiar anymore, and their works were therefore listed as anonymous. Some other masters of the same generation, such as Pieter de Molijn, Dirck Hals, Jan Miense Molenaer, or Pieter Codde, became frankly obscure. These painters, who were highly popular during the second quarter of the seventeenth century, were only mentioned in passing or not at all by the biographer Arnold Houbraken. In eighteenth-century auctions, their names all but disappeared.

Although Van Goyen's fame never sank so low, his name does not appear in Houbraken's list, drawn up in the early eighteenth century, of the sixty most renowned painters active between 1560 and $1660 .{ }^{90}$ He shared that fate with all painters who used the rapid and "monochrome" 
technique, with one exception: Jan Porcellis. Apart from Jan Porcellis, the canon had shrunk to painters who worked in a refined style with bright colors. As Gerard de Lairesse put it, "dirty and grayish-green colors" no longer pleased the eye. ${ }^{91}$ The only landscape painters of Van Goyen's generation to survive on Houbraken's list were Cornelis van Poelenburch and Bartholomeus Breenbergh.

\section{Monochromy, Virtuosity, and "Realism"}

For viewers today, Van Goyen's "monochrome" coloring is probably the most striking aspect of his work. Indeed, many painters of his generation-including still-life painters and genre painters - used a restricted scope of mostly brownish, yellowish, and greenish colors, but Van Goyen applied this palette in the extreme through the 1630s and 1640s. The word "monochrome" is used for the sake of convenience; naturally Van Goyen's paintings are never entirely monochrome, and every few years he changed his coloring slightly. ${ }^{92}$ As we have seen, this coloring facilitated a rapid, inexpensive production technique. Esaias van de Velde and Jan Porcellis were the ones who first experimented with a radically reduced range of colors, combining this with a fluent, brisk application of paint on a thin ground. ${ }^{93}$ By using only a few colors, they could accelerate their pace, restrict the number of palettes to one, and paint "wetinto-wet," which saved labor costs. ${ }^{94}$ And with the production of a larger number of paintings, the material costs could also be reduced; ochers and other earth colors were in fact the cheapest. $^{95}$

As we concluded above, this quick and cheap production did not diminish Van Goyen's high appreciation by connoisseurs. Notably, Van Hoogstraten maintained that many painters chose this manner of working to obtain not only "profit" but also "fame." Thus the economic motivation must have gone hand in hand with the artists' ambitions to distinguish themselves artistically. These painters aimed for a high degree of virtuosity that gained them the connoisseurs' admiration. It is not by chance that Van Hoogstraten's description of Van Goyen's painting technique during the "painter's contest" with Porcellis and Knibbergen concentrates on the fabulous virtuosity with which Van Goyen-in a heartbeat-conjured up a whole range of motifs out of nothing. He relates how Van Goyen first loosely covered (overzwadderde) his whole panel, "here lighter, there darker, more or less like a multihued agate or marbled paper." He then:

“... began to seek out all kinds of amusing things, visualizing them with great facility through many small brushstrokes. Thus, in the distance, a pleasing view with farmhouses appeared, and nearby one saw emerging an old town wall with a water gate and jetty reflected in the rippling water, and ships and barges laden with cargo or travelers leaving and arriving. In short, his eye, as if trained to pick out all kinds of things that were hidden in a chaos of paint, steered his hand and mind swiftly, so that 
one was seeing a perfect painting before one well and truly realized what he intended to do ${ }^{96}$ (see, for example, fig. 9).”

Van Hoogstraten's emphasis on the apparent chaos out of which-as if by chance-many visible things quickly appear and then merge into a perfect painting reflects the amazement and admiration that viewers of the time had for a casual, virtuoso handeling (manner of painting). ${ }^{97}$ With this handling, Van Goyen responded to contemporary connoisseurs' high appreciation for artists' seeming nonchalance in achieving a convincing rendition of the real world. "How is it possible that the brush can suggest so much softness with such rough touches and such unattractive colors, and that by way of such casualness one can produce something so agreeable?"98 These words, from a French pamphlet of 1635, were suggested for people who, while visiting a workshop, wanted to say something intelligent. They apply well to works by Van Goyen.

Van Goyen seems to have used a rapid painting technique and monochrome colors to show off his breathtaking ability to suggest all visible things-substance, texture, space, and atmosphere. He accomplished this with the most limited means: little time, limited and cheap materials, and a range of only a few closely related color gradations. When his method was successful, and when it sparked the admiration of many liefhebbers, his art's most eye-catching features became a fashion followed by many others.

It is curious that art historians in the twentieth century again and again emphasized that through this "monochrome" or "tonal" manner of painting, which reached its peak in the 1640s, Van Goyen was able to render realistically the singularity of the Dutch landscape and its humid atmosphere. Not only foreign but also Dutch art historians repeated this continually. ${ }^{99}$ The Dutch should have realized the artificiality of this coloring; in no way does it present a "realistic" image of the Dutch landscape. Apparently, their mental image of the Dutch landscape was influenced by their admiration for Van Goyen's depictions. Perhaps this notion originated in the second half of the nineteenth and the first half of the twentieth centuries through the experience of black-and-white photographic landscapes, which aimed at an atmospheric rendition of the landscape through the careful refinement of monochromatic tones.

47 Few other painters have been able to suggest the atmosphere of the Dutch "waterland" as convincingly as Van Goyen, but he accomplished this rather in spite of his monochrome manner of painting. For Van Goyen's and Molijn's dunescapes from the late 1620s and early 1630s, the limited palette, with its many gradations of yellows and browns, is appropriate. But brownish or grayish-green tones are not at all characteristic of Dutch pastures, lakes, and rivers, which Van Goyen depicted in large numbers from the 1630s until his death in 1656. On the contrary, bright colors characterize the Dutch waterland, which was depicted as such by painters of the younger generation: Paulus Potter, Willem van de Velde the Younger, and the latter's brother Adriaen. ${ }^{100}$

The colors of Dutch pastures and waterscapes become muted only when fog develops. But when that happens, visibility is seriously limited and the details of the far distance vanish, whereas in 
Van Goyen's depictions, many details are present on the horizon. Moreover, under actual foggy conditions, a graying of the colors takes place, while nearby the manifold hues of the landscape still remain.Many authors see a misty atmosphere in Van Goyen's paintings, but there is never any discernable fogginess in his works. The sentence with which Van de Waal finishes his book- "His art knows no doubt other than that of the mist above the water and no delight other than the triumphing light"-is splendid, but only the second part of the sentence characterizes Van Goyen's work (Van de Waal, Jan van Goyen, 60). ${ }^{101}$ In his paintings, however, Van Goyen always suggests that the clouds are parting; when that happens, the Dutch waterland presents a wealth of strong colors. Therefore, brown meadows, light brown water, hazel-colored surfaces of ice, and yellowish-brown towns and town walls along a river or in the distance are all totally artificial. As demonstrated above, Van Goyen introduced this palette in conjunction with his new manner of production. Simultaneously, the muted palette became an aesthetic ideal. Long before the arrival of black-and-white landscape photography two and a half centuries later, Van Goyen knew how to achieve a convincing atmospheric effect through the incredible refinement in gradations of one color, creating the impression of immeasurable distance.

Moreover, the effect of a distance in which all shapes, through their light colors and indistinct contours, often seem to dissolve at the horizon into the cloudy sky is not because Van Goyen painted a very humid atmosphere but because he painted the landscape almost contre-jour. From the beginning of the 1630s on, Van Goyen frequently depicted his scenes as if the viewer is facing the light - while the sun hides behind the clouds - which usually comes obliquely from left of center (fig. 10). In such circumstances, the humidity in the air causes a stronger effect of blurring than when the light comes entirely from the side, or when one looks in the same direction as the light. Cornelis van Poelenburch was probably the first to introduce the effects of backlighting in his Italianate landscapes (fig. 11). ${ }^{102}$ In the second half of the 1620s, Porcellis was the first to achieve this effect in his water landscapes, and thereafter Van Goyen implemented this idea in his own landscapes. Van Goyen's contre-jour effect was not the low, yellowish backlight skimming the ground that such Italianate painters as Jan Both and Nicolaes Berchem adopted (suggesting the light of morning or evening), but a clear backlight from a cloudy (but not fully covered) sky in the middle of the day.

Van Goyen depicted immense distance breathtakingly. On a miraculously small strip of painted surface (usually only a few centimeters high), he was able to suggest a view across flat (water)land many kilometers deep. If he had rendered this narrow strip of landscape with an abundance of colors more based on reality-with many strong colors in the foreground that change into paler grayish hues in the background-he would never have been able to achieve this atmosphere of intense, vast calm. This calm characterizes most of his landscapes despite the manifold activities they contain. As Van de Waal astutely remarked, his atmosphere can best be described by the untranslatable Dutch word stemmigheid (something like "subduedness"). ${ }^{103}$ By stimulating the eye with the fewest possible colors-especially in his paintings from the mid1630 s on-Van Goyen subordinated all elements in order to achieve this quiet and calm. His seemingly simple, but very sophisticated, compositions contribute to this result. 
In a few cases, contemporaries compiling inventories considered the monochrome quality of a Van Goyen painting so prominent that they called it een grauwtje (a grisaille), the same term used for the truly monochrome works of Adriaen van der Venne. In Jan van de Cappelle's collection inventory, for example, these "grisailles" from Van Goyen's oeuvre were recognized as a separate category: two of the ten works by the master are described as such. ${ }^{104}$ The same qualification, incidentally, was also given to several paintings by Porcellis and Esaias van de Velde (and to an Ecce Homo by Rembrandt). In the case of the Van Goyens, it probably describes a number of small, late works in which indeed almost all color has been expelled and the whole has been painted in variations of gray-brown. This is most conspicuous in a group of works painted in oil on paper, all of them dated between 1650 and 1651 (fig. 12). ${ }^{105}$ With other works-especially the larger and more elaborate pieces-we must allow for the possibility that the blue in the sky might originally have been stronger. Houbraken stated that Van Goyen's paintings "usually ... are somewhat monochrome or gray: but that is not how they were painted at the beginning; in that time there was a color they called Haarlem's blue, not used anymore because it is not stable, that was the cause thereof." This remark has often been dismissed; Houbraken may not have understood the effect Van Goyen aspired to. ${ }^{106}$ Since Houbraken was surely well informed of the painting practices of the generation before him, David Bomford assumed that this Haarlem's blue may have been a cheap quality of smalt that can indeed discolor to yellow-gray in an oil medium. ${ }^{107}$ \{Melanie Gifford, however, doubts that Van Goyen used a smalt that later discolored; in her view, the considerable variation in his late work-where some paintings feature a smalt that is rather brightly colored and others include a smalt that is almost colorless-indicates that these differences were a matter of choice. $\left.{ }^{108}\right\}$

\section{Youthful Ambition}

Van Goyen developed his most characteristic style (the rapid manner of painting, the elimination of local color) only after he had been working as an independent master for almost ten years; by that time, he had acquired a reputation for paintings with colorful, detailed figural staffage (fig. 13). He began his career as an independent artist after an exceptionally long and relatively expensive apprenticeship. ${ }^{109}$ This long training is probably indicative of the ambitions of his father, a shoemaker whom Orlers called "a lover of draftsmanship and the art of painting." The young Van Goyen started his training at an early age, when he was only ten years old; ${ }^{110}$ thereafter he served about eight years as an apprentice to no fewer than five different masters. After he traveled to France and had been working on his own for some time, his father acknowledged that "he was well advanced in the art of painting and that his son aspired to be able to move further." Only then, around his twentieth year, did he apprentice with "the excellent, renowned landscape painter Esaias van de Velde, with whom he stayed for a whole year." ${ }^{111}$ Both father and son Van Goyen took great pains for Jan to experience as thorough an education as possible. Finishing his training with Esaias van de Velde was a well-informed choice, as Van de Velde's specialty and particular skills were those that the young Van Goyen wanted to acquire. This choice lastingly determined the character of Van Goyen's work. 
When we compare Van Goyen's paintings from his early period (1620-1626) with the landscapes Esias van de Velde made while the young painter was his apprentice, we see that, on the one hand, Van Goyen made considerable use of the local landscape motifs that Van de Velde depicted in paintings, drawings, and prints (figs. 3a, 14). On the other hand, the young painter wanted to distinguish himself by combining these motifs with a more precise and colorful manner of painting and more richness of vivid details (figs. 13, 15). In this regard, he followed in the footsteps of many older masters, from Hans Bol to Jan Brueghel the Elder (fig. 16), David Vinckboons, and Hendrick Avercamp (fig. 17). In addition, he became-and his contemporaries were quite aware of this-a very competent painter of figures. Other landscape painters even asked him to paint their figures. ${ }^{112}$

More faithfully than his master, Van Goyen followed Karel van Mander's advice to be sure to strive for "much diversity of colors as well as of nature ... / Because that brings great and laudable beauty." 113 Van Goyen combined Esaias van de Velde's highly innovative landscape type, in which the local Dutch countryside is rendered with a swift brush, with this call for "varietas" (Van Mander's verscheydenheyt, diversity). ${ }^{114}$

Perhaps the young Van Goyen found a justification for his style in a famous example from antiquity, striving to match the antique painter Ludius, whom Van Mander, in his account of "diversity in landscapes," mentions as the greatest example of an artist who enriched his paintings with a large variety of motifs. ${ }^{115}$ Moreover, Van Mander's account reads as though he perceives Ludius's work as the portrayal of a directly experienced environment. When Van Mander records that Ludius's admirers considered a painting of a low swamp with farmhouses and slippery, muddy roads to be his best work, it is almost as if Ludius were a Dutch landscape specialist. ${ }^{116}$ This might even have encouraged artists to avoid uitheemse pronk (embellishing motifs that are foreign), in the words of the poet Spiegel. ${ }^{11}$

Some parts of Van Mander's account of Ludius's landscapes, which are repeated (in prose) in his biographies of antique painters (all derived from Pliny), read almost like a description of early work by Van Goyen (see fig. 15). In his landscapes, Ludius painted people who "strolled outdoors for recreation, or spent their time boating for pleasure." He also depicted donkeys and loaded wagons next to farmhouses, and various other rural activities like men fishing, catching birds, or hunting. ${ }^{118}$ Van Mander's observation that Ludius demonstrates how a Const-lustighen gheest (somebody with an artful mind) can achieve wonderful results would have been an inducement for a young and ambitious painter to imitate the ancient artist. We cannot know whether the young Van Goyen deliberately emulated this example from antiquity and thus, in his own way, "revived" Ludius's style. ${ }^{119}$ However, it seems likely that the story of Ludius, "the first inventor who set himself to painting landscapes," and whose example generally supported the self-respect of all painters specializing in landscapes in this period, was common knowledge in the workshop of such a famous landscape painter as Esaias van de Velde. ${ }^{120}$

57 Although Van Goyen's early paintings undeniably represent a personal, identifiable type of landscape that would have been recognized as such by his contemporaries, none of his motifs are in and of themselves absolutely new. It is not only to the work of Esaias van de Velde (and of the 
older generation of landscape painters mentioned above) that we can trace Van Goyen's landscape motifs, human figure types, and activities. The repertoire as realized in the many print series by Claes Jansz. Visscher and Jan van de Velde II (figs. 18 and 19), which had become popular in the previous decade, appears to have been crucial for Van Goyen. By selecting his motifs with care, he allowed the viewer the opportunity to peruse numerous vivid (stereo)types-farmers, fishermen, hunters, city people, soldiers, horses, dogs, cattle-going about their business in a peaceful country village on the border of the dunes and waterland. In the imagination of the well-to-do town dweller, these were "pleasant" places. ${ }^{121}$

As a young painter who had to establish a name for himself, Van Goyen chose a path without too many risks; he adhered to motifs that were already well known and types of paintings that Esaias van de Velde had successfully introduced. This is not only true for his summer landscapes with village views, but also for the "winters" (figs. 13a, 20). ${ }^{122}$ In these, he combined many elements of the styles of two popular masters, Esaias van de Velde and Hendrick Avercamp. The compositional motifs (a castle in the middle ground, a bare tree as a repoussoir) as well as the large number of cheerful staffage details often recall the Flemish tradition to which Avercamp's work directly connects.

As in his other early paintings, Van Goyen combined these features with motifs he had learned from Esaias van de Velde (fig. 21), such as a lower viewpoint and a tighter organization of the figure groups along compositional lines leading into the distance. The atmosphere of wintery bareness and chilliness that Esaias van de Velde often strove for in his sober winter landscapes did not appeal to Van Goyen. He was especially concerned with a great "variety" and a proud display of his capabilities as a figure painter, elements with which he, as a Dutch Ludius, aimed to draw the attention of the liefhebber. Judging by Huygens's remarks (written in the beginning of 1631), he succeeded.

\section{A Change of Course}

The transition to another type of painting took place rather abruptly. In 1627, Van Goyen had the courage to change this type almost overnight, possibly in the face of increasing competition (fig. 22). ${ }^{123}$ From then on, he no longer displayed his ability through a richness of motifs and details but through a seemingly casual ease in suggesting an environment based on drawings after nature - the inner dunes (at the time deforested), with some dry vegetation and a few farmhouses or a country inn here and there. All these motifs could be found in abundance in the countryside between Haarlem, Leiden, and The Hague and were familiar to inhabitants of those towns.

Pieter de Molijn and Pieter van Santvoort-building on motifs that Esaias van de Velde had introduced in prints and paintings around 1614 (figs. 3b, 23) - were probably the first to transform Esaias's van de Velde's innovations into this new type of dunescape (fig. 24). ${ }^{124}$ They did so slightly earlier than Van Goyen, and Van Goyen must have recognized the possibilities immediately. He might have begun producing these unadorned dune landscapes initially in 
competition with Molijn, whom he surely knew from the period of his apprenticeship in Haarlem. Van Goyen's experiments with this new type turned out to be very successful.

62 The young Salomon van Ruysdael immediately embraced this subject too, while Van Goyen's Leiden contemporary Pieter de Neyn (another competitor) ${ }^{125}$ also followed in the same year, 1627. These painters, it seems, began to bid against each other in simplifying their compositions and color palettes as much as possible. The limited range of yellow, brown, and pale green tones was very appropriate for this type of landscape. Even more than the others, Van Goyen went to the extreme, displaying virtuoso mastery with a minimum of means for maximum effect (fig. 25). ${ }^{126}$ Thus, for Van Goyen and some of his most talented colleagues, economic and artistic endeavors merged perfectly.

63 The farmhouses in particular, with their irregular and sometimes even fantastic shapes, still guaranteed a certain "varietas," despite their coloristically austere environment. They are poor and shabby, but by seventeenth-century standards probably not alarmingly dilapidated (fig. 26, 27). ${ }^{127}$ In combination with the chatting or quietly strolling country people, these motifs may have presented to the urban audience a comforting image of simple rural life, where one is free of desire and pride and content with the basic essentials of natural existence. ${ }^{128}$ Given Van Goyen's vast output, clients must have considered the dunes an attractive landscape type. In an age in which the representation of nature was viewed as praise for God's creation, ${ }^{129}$ it is possible that for the people living in the cities of Holland the image of the dunes-as protectors of the land against sea-read as a manifestation of God's grace. "God's goodness is apparent from the top of every dune," Constantijn Huygens wrote. Moreover, the citizens of Haarlem, Leiden, and The Hague saw the dunes as a major destination for relaxing walks or amusing outings. That, too, would have contributed to this landscape genre's popularity. ${ }^{130}$

In these works, Van Goyen and other artists increased the viewer's involvement with the depicted landscape through a radically changed viewpoint. In Van Goyen's early landscapes-as with all landscape paintings by Esaias-we see the land and the figures somewhat from above, as if we, the viewers, are standing on a raised part of the land, a mound, or a small hill, or looking out from an upper-floor window (fig. 28). In that way, characteristic of sixteenth- and early seventeenth-century scenes, all figures are situated at different distances below the horizon. This makes possible the representation of a large number of figures over all the planes, from foreground to background.

65 In 1627, however, Van Goyen started to paint landscapes in which the viewer is positioned at a much lower vantage point (fig. 22) - an experiment that he continued systematically in 1628 and 1629 (figs. 2, 25, 26, 27). The eye of the viewer-indicated by the horizon-is now at the same, or almost the same, height as that of the figures within the image. The viewer is standing, as it were, at the same level and looks straight at the figures or even up at them when they are placed on an elevation in the landscape or on a wagon that raises them above the horizon. ${ }^{131}$ The suggestion that we are looking at a landscape rendered "from life" is therefore much more convincing. ${ }^{132}$ Sometimes our view is limited because we look against a rising dune, so that we cannot see the horizon hidden behind the dune. Then we see only the top of a farmhouse, the 
crown of a tree, a spire, or the heads of the figures emerging above, an effect that is typical when strolling in the dunes. The borderline between our world and the world in the painting is eliminated as much as possible; it seems as if one could just walk into the landscape.

In previous years, Van Goyen had rendered the low viewpoint many times in his drawings (fig. 29), but from this moment on he used this method in paintings as well to create a much more direct confrontation with the suggested surroundings. Along with the shift in viewpoint, he had to reduce the figural staffage considerably, at least in the foreground. When the eye level of the viewer and the figures in the painting are the same, the figures in the foreground (so frequently present in earlier works [figs. 13, 15, 20, 28]) need to disappear. They would otherwise cover a large part of the landscape and become too dominant, as we see sometimes in drawings of the period that are primarily figure studies (fig. 30). Van Goyen had to place the figures much deeper in the landscape. Apart from the elimination of the figures in the foreground, a radical reduction in number of figures within various planes was necessary as well; when the horizon is at the height of the represented figures' eye level, they would mostly overlap each other. Moreover, a monotonous isocephaly (all heads at the same level) would occur. In order to prevent this, the smaller number of remaining figures are placed at different levels: under the horizon, by rendering them in a sitting position, and above the horizon, by placing them on a mound, a little hill, or a wagon.

The feeling that one could just walk into the landscape, like a stroller on the road through the dunes, is amplified by strong "lines of perspective" created by the country roads, buildings, and vegetation that together emphasize receding movement into the far distance. Previously, the farmhouses, trees, and other motifs were placed behind each other as parallel screens (fig. 28), but now they are linked together by placing them, as it were, along oblique lines (which have often been called "diagonals" by art historians) that lead the eye into the distance, at the same time shaping those lines (fig. 27). Thus, a forceful thrust into space is achieved. Not only does it guide the eye into depth; it also creates a suggestion that the depicted space extends forward out of the painting to continue, as it were, into the viewer's own space.

The low viewpoint, the strong spatial movement, and the reduction of the many motifs reinforce the "from life" (naer het leven) effect of the paintings. The illumination contributes to that effect as well. In the early landscapes, the contrast between the conventional dark strip in the foreground and the lighter middle plane is totally artificial. It provides a means to create a sense of space (fig. 28). As of 1627, the natural source is indicated: a strong shaft of sunlight slants from the left side, cutting across the middle plane; all elements are sharply lighted against the darker parts around them. The parting of the heavily clouded sky accounts for these seemingly sudden, bright sunbeams. All these changes allow viewers not so much to "read" the landscape with figures as to invite them to take part in it and enjoy it themselves. 


\section{A Continuing Source of New Types of Landscapes}

Van Goyen's production of dune landscapes found its apogee in the years 1631-1633. Afterward, the number dropped rapidly, and as of the mid-1630s, he only rarely painted such subjects. Although Molijn and many followers of Van Goyen continued this type of landscape much longer, Van Goyen apparently lost interest. The subgenre probably became less lucrative once his dune landscapes were available in large numbers. His followers apparently wanted a piece of the pie, flooding the market with numerous "dunes." Van Goyen himself switched to new subjects. The river view became especially important for him, and later on views of open water with passenger boats and fishing vessels.

70 I will not discuss in detail Van Goyen's immensely rich production of paintings from the 1630s until his death; that has been done several times. ${ }^{133}$ Here I will only indicate that again and again, after having produced a certain type of landscape in large quantities over the years, and seeing it adopted by others, Van Goyen developed a new theme and added it to his repertoire. ${ }^{134} \mathrm{He}$ continued to innovate to keep clients' interest in his works alive, and by doing that his art became a source of new types that were taken up immediately by many followers. Usually Van Goyen had already tried out, earlier, the subjects that he then later adopted for production on a larger scale.

As noted, besides (and after) the dune pictures, Van Goyen developed river views dominated by the river's surface and a cloudy sky reflected in the water. He started this type in 1628. With their somewhat sandy shores and simple farmhouses, the paintings seem to render the landscape around the Oude Rijn (Old Rhine) between Leiden and Katwijk. Perfecting it during the 1630s (see fig. 10), he applied the "monochrome" coloring and rapid painting technique that he had originally developed for the dune landscapes. From 1634 on, he added a new variation in which the rivers are lined with castles, town walls, or other distinctive architecture. In the second half of the 1630s, his production of this type of landscape grew; throughout the 1640s, he painted them in large numbers (figs. 9a, 31). ${ }^{135}$

During the first half of the 1630s, when Van Goyen's interest in the dunescape had passed its peak, the beach view first appears in his oeuvre; these works feature the church tower of Scheveningen (fig. 32) or Egmond many times, a subject he had already tried out occasionally. ${ }^{136}$ Especially in the 1640s, he painted numerous beach scenes (fig. 33), after which the number of paintings with this subject suddenly decreased considerably; in the 1650s, he produced them only incidentally. Van Goyen's views of open water began, so far as we can trace, in 1636. This ${ }^{137}$ was once the specialty of Jan Porcellis, his senior by about fifteen years, whom he had known personally. Only after Porcellis's death some years earlier, in 1632, did Van Goyen try his hand at such a subject. He must have seen a gap in the market, the more so since works by Porcellis had begun to yield high prices. Van Goyen's early pieces in this subgenre are unmistakably related to those of the older master (fig. 34).

Although Porcellis's work stimulated him at first, Van Goyen developed a personal type of openwater scenes in the late 1630s (fig. 35): wide, quiet views, mostly of lakes or estuaries with towns 
or villages in the far distance. Here, with breathtaking mastery and extremely limited means, he suggested an unbelievable vastness and compelling tranquility. He achieved this effect by subtle transitions of tone in the water and clouds, and by the unerring placement of vessels in the suggested space. At the same time, he drew the ships and many human figures on them with flawless perfection. During the last years of his long career, he must have found great success with just these works, because his late production largely consists of views of such calm waters. His clients, and he himself, would have been aware that he produced paintings of unequaled quality in this genre (fig. 36). ${ }^{138}$

74 Van Goyen's panoramic views flourished for a shorter time. He started this genre-probably inspired by Hercules Segers's works - with views of Arnhem and Rhenen seen from the land side (in 1633 and 1636, respectively; fig. 37). Thereafter he depicted The Hague in the same way. From 1639 until 1647, he frequently made panoramic views in which not the town in the distance but the vast view itself plays the main role (fig. 38). After 1647, as far as we know, he abruptly stopped painting these large panoramic scenes.

The many views of such towns as Dordrecht, Nijmegen, Rhenen, and Arnhem, seen from the water, began to appear in Van Goyen's work in the 1630s, at first rather hesitantly with views of Dordrecht and Nijmegen in 1633. The earliest views of Arnhem and Rhenen from the side of the river date from 1639 and 1641. In these paintings, Van Goyen combined the older tradition of the painted town profile-by such artists as Hendrick Vroom - with the river view or wide water view he had developed himself. By the end of the 1630s, these works became a great success; from that time until his death-reaching a pinnacle between 1641 and 1651-he would produce many views of towns along a river, especially Nijmegen (see fig. 8), Rhenen (fig. 39), Leiden (fig. 40), and Dordrecht (fig. 41), some of them very large in size. ${ }^{139}$ It is notable that in some years Van Goyen painted one town many times: 1644 and 1647 are peak years for Dordrecht (we still know five and six from these years, respectively) and 1646 for Nijmegen (six). Through the rich staffage of ferries, fishing boats, and sailing boats with passengers, and by changes of viewpoint and shifting of architectural elements, he continually provided remarkable variation. ${ }^{140}$

The ice landscape, finally, is the only genre that Van Goyen painted throughout his life. It had its first peak from the beginning of his career until 1627 (figs. 13b, 20a). After that, he painted the subject only incidentally; but it flourished again in the first half of the 1640s (fig. 42). Thereafter the number diminished, although he still made an ice landscape occasionally until the end of his life. ${ }^{141}$

As noted above, during the late 1620s and 1630s, Van Goyen worked with powerful "perspective lines" that pull the eye into the distance, at the same time experimenting more and more with the effects of backlighting. In that period, the viewer's eye level is mostly about the same as that of the standing figures in the image. The foreground, for the most part, remains empty, and the figures are usually placed rather far into the distance. In the river landscapes, for example, the viewpoint is very low, as if the viewer were seated in a rowboat, or sometimes a bit higher, as if they were standing on the deck of a boat gliding over the water along the bank of a river, thus able to look infinitely far over the calm water toward the horizon. 
In the 1640s, Van Goyen began to experiment with different, much more complex compositional devices. The dominance of the "perspective lines" ("diagonals") leading the eye into the suggested space diminishes considerably, and often they are intersected by elements that are parallel to the picture plane. The eye level of the viewer becomes more varied. Van Goyen often chose again a higher viewpoint, as if the viewer were standing on a high shore (in river landscapes) or on a low dune (in beach views). This higher viewpoint makes it possible to introduce more staffage in the foreground: a little boat with fishermen, a promontory with cows in the river in water landscapes, or in beach views, for instance, a little dune with some figures. On the other planes of the picture, too, space is dedicated to more figures; especially in the ice landscapes and beaches, Van Goyen could enjoy himself fully by depicting all kinds of human activities.

Not a breath of wind stirs in most of Van Goyen's landscapes. In the river- and waterscapes the smooth surface of the water reflects clouds, the shores, and the boats. Sometimes the clouds seem to threaten, suggesting that the weather is going to change. On rare occasions, there is a strong wind. Only in a small number of paintings, all dated in the early 1640s, does Van Goyen explicitly depict bad weather with rain, a storm, or lightning (fig. 43). $\left\{{ }^{142}\right\}$

80 The languorous peace characteristic of so many of Van Goyen's works reached a high point in his wide expanses of water of the 1650s (figs. 36a, 41a): summer days when the wind has dropped, and the fishing boats, yachts, and sailing barges full of passengers seem to sway gently on the calm water. A fine poem by the clergyman Jodocus van Lodesteyn (written between 1650 and 1653) evokes a similar atmosphere, leading the poet to religious reflections, but only after he first gives a beautiful description of an experience so familiar to every traveler in that time:
Did one ever see calmer weather?
The flags are drooping,
The sail is sagging,
And the only headway is made through the slow-moving tide. $^{143}$

81 This essay placed the emphasis on Jan van Goyen as a "homo economicus." Producing works in an economically efficient way, the painter was able to maintain a position as a market leader throughout his whole career. In an art market where the competition must have been fierce, he achieved this by developing and applying a style that was always recognizably "Van Goyen", while time and again introducing into his repertoire new types of landscapes, which he continuously expanded and renewed. Subsequently, many others imitated his landscape types, which then became specialties of painters of a second tier. ${ }^{144}$

Van Goyen must have depicted this landscape with unflagging enthusiasm and intense love; his countless drawings testify to this as well. The first quality Samuel van Hoogstraten demanded of a good painter is that he "is in love with depicting the pleasantness of beautiful nature." ${ }^{145}$ Jan van Goyen seems to have more than met this requirement. We can only agree with Willem 
Martin, who wrote in his unsurpassed 1930s survey of Dutch art: "But above all, Van Goyen is the gifted painter of the clouded Dutch sky and of everything that is dear to us in its watercourses and rivers." ${ }^{146}$ I would add that the image of what is still precious to us in the Dutch landscape has been a good deal shaped by Van Goyen's paintings. It is a miracle that such seemingly simple compositions were able to exert such a far-reaching effect. Many centuries later they still define our image of how breathtakingly beautiful the Dutch landscape can be-we still look for it when walking in the dunes or sailing over the lakes and rivers, even as we try to ignore the many signs of modern life.

\section{Postscript}

This article was written in 1995/6 as an essay for the catalogue accompanying the exhibition Jan van Goyen in Museum de Lakenhal, Leiden (October 1996-January 1997). The catalogue presented new approaches to Van Goyen's work by Edwin Buijsen, Reindert Falkenburg, Melanie Gifford, and me. ${ }^{147}$ During the fall semester of 1995, I had held a seminar on Jan van Goyen at Leiden University, which greatly contributed to my thinking about his career and work. I made grateful use of students' papers in the last part of the article. ${ }^{148}$

The present version of the article, which was translated for JHNA by Nicolette Sluijter-Seijffert and edited by Alison M. Kettering, is based on the original manuscript. It is more complete than the Dutch article published in the catalogue-at the last minute, before the catalogue was printed, sentences, parts of sentences, indeed whole paragraphs were cut because of the need to reduce the number of pages.

The essay's goal was to examine Jan van Goyen's painted oeuvre-with regard to its production, style, development, themes, and compositions-from different perspectives than had been usual up until then. New research on the art market by John Michael Montias and Neil de Marchi and Hans van Miegroet; on probate inventories by Willemijn Fock and Pieter Biesboer; and on technical art history by David Bomford and E. Melanie Gifford stimulated me to think about the "strategies" that ambitious artists might have used, consciously or unconsciously, to position themselves within the art market, making choices with respect to style, subject matter, and technique to target an audience in order to secure a place among a range of colleagues working in the same field. These artistic and economic concerns were often inextricably linked. Now, in rereading the article, I find all of this self-evident, but at that time it was thrilling and new. Jan van Goyen appeared to be the artist par excellence on whom to try out such research, even though I had never before immersed myself in landscape painting.

The second part of the article is devoted to a discussion of Jan van Goyen's radical change in style and continuous innovations in types of landscape that were, in my view, directly related to his aspirations as a market leader in his field. This might sometimes read as a lecture for firstyear students on visual analysis. But before the 1996 exhibition, descriptions of Van Goyen's stylistic development were still given in purely formal terms, as if he were making abstract paintings, using "diagonals" ("a diagonal pattern," "a diagonal-triangular scheme") and reduced 
color only to "unify" the structure of his compositions. In that approach, characteristic of the first three-quarters of the twentieth century, there are no viewers whom the artist aims to involve in what is represented, let alone viewers who endeavor to imagine the scene before their eyes as a "real" space; a "virtual reality," we might say now. ${ }^{149}$

More seventeenth-century inventories have been published (online) than those that were available at the original time of writing, although their numbers are still fewer than one would wish. The Getty Provenance Index now provides all the Haarlem inventories transcribed by Pieter Biesboer; the Montias Database contains all the inventories on which Montias based his article on works of art in Amsterdam. Piet Bakker provided me with more information about the Leiden inventories assembled by Willemijn Fock, among them the correct archival references. Because only a few more Van Goyen paintings with valuations have turned up than the ones I knew at that time, the average estimates I calculated when writing the 1996 essay remain more or less the same; apart from correcting a mistake in a footnote, only in one instance did I add \{between curly brackets\} information on estimates I did not have at the time.

In general, it is remarkable that, as far as I know, little has been published on Van Goyen and painters around him since the 1996 exhibition and catalogue, apart from a stimulating 1998 article by Reindert Falkenburg that both builds on Montias's and my theses and takes issue with some of them. ${ }^{150}$ Art-historical interest in the depiction of the Dutch landscape seems to have waned over the last few decades. Yet the enormous surge in the production and collecting of landscapes representing the local environment-which, though not expensive, appealed more to sophisticated audience than to buyers of modest means-remains a fascinating phenomenon that deserves new research to deepen our understanding of seventeenth-century Dutch painting.

\section{Biography}

Eric Jan Sluijter is Professor Emeritus of the History of Renaissance and Early Modern Art at the University of Amsterdam (2002-2011). He worked at the RKD (1972-1976), taught at Leiden University (1976-2001), and served as visiting professor at Yale University (1991), The Institute of Fine Arts/New York University (2002-2007) and Harvard University (Erasmus Lectureship, 2019). For his publications, see www.ericjansluijter.nl.

\section{E.J.Sluijter@uva.nl}

Nicolette Sluijter-Seijffert studied at Leiden University, where she received her PhD in 1984 with a dissertation on the Italianate painter of landscapes and figures Cornelis van Poelenburch. She was employed for several years at Leiden University and served as curator at the Mauritshuis from 1981 until 1986. Between 1986 and 2003 she was director of Museum het Catharina Gasthuis and Museum De Moriaan in Gouda. Her monograph Cornelis van Poelenburch 1594/95: The Paintings was published in 2016 (Amsterdam/Philadelphia: John Benjamins). 


\section{Illustrations}

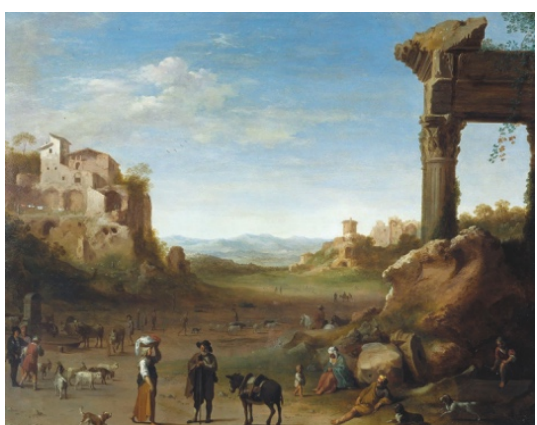

Fig. 1 Cornelis van Poelenburch, Landscape with Ruins and Figures, oil on copper mounted on panel, $31.7 \times 40 \mathrm{~cm}$. Collection HM Queen Elizabeth II, Buckingham Palace / Windsor Castle, London (artwork in the public domain)

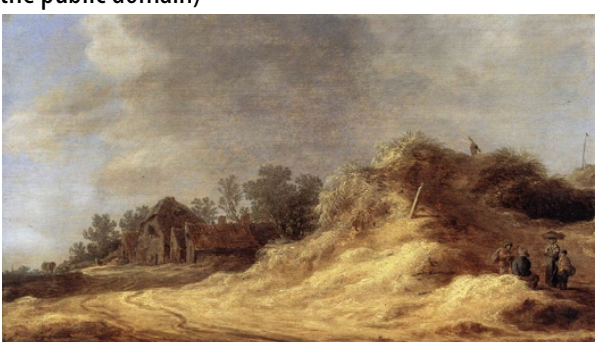

Fig. 2 Jan van Goyen, Dune Landscape, 1629, oil on panel, $29 \times 51 \mathrm{~cm}$. Gemäldegalerie, Berlin, inv. no. 865 (artwork in the public domain)

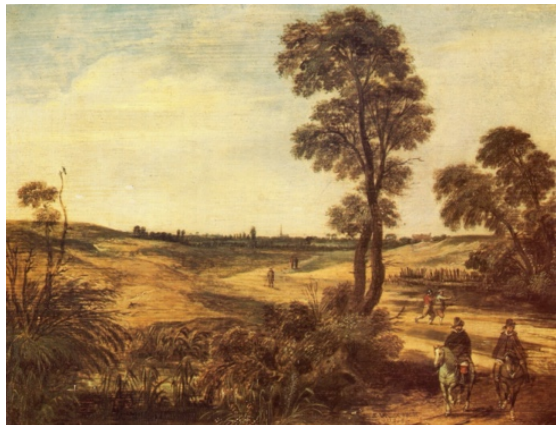

Fig. 3 Esaias van de Velde, Two Horsemen in a Dune Landscape, 1614, oil on panel, $25 \times 32.5 \mathrm{~cm}$. Rijksmuseum Twenthe, Enschede, inv. no. 0079 (artwork in the public domain)

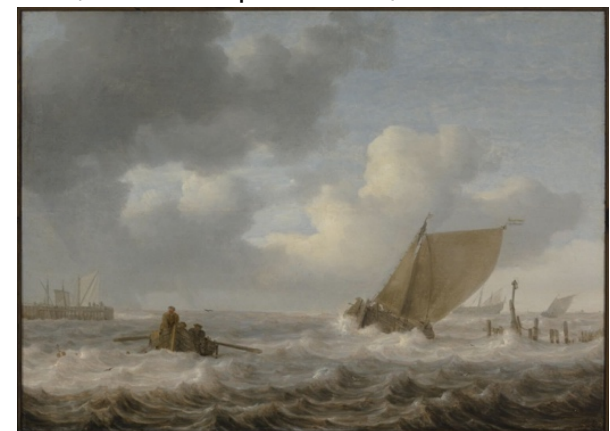

Fig. 4 Jan Porcellis, Estuary with Ships in Stormy Weather, ca. 1630, oil on panel, $58 \times 80.5 \mathrm{~cm}$. Museum Boijmans van Beuningen, Rotterdam, inv. no. 1675 (artwork in the public domain)

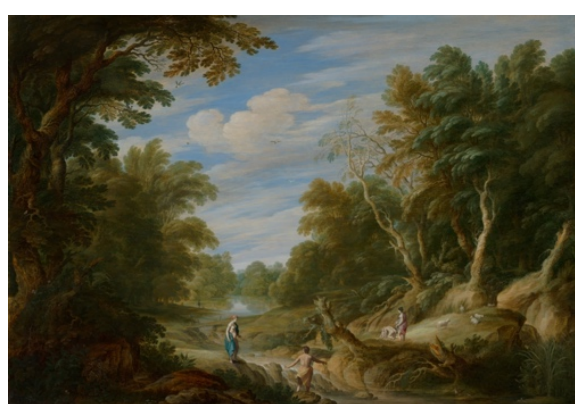

Fig. 5 Alexander Keirincx and Cornelis van Poelenburch, Wooded Landscape with Figures, 1629 , oil on panel, $64 \times 92 \mathrm{~cm}$. Mauritshuis, The Hague, inv. no. 79 (artwork in the public domain)

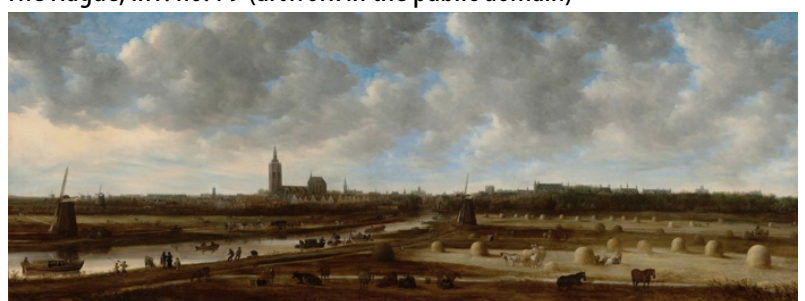

Fig. 6 Jan van Goyen, View of The Hague from the South-East, 1651, oil on canvas, $170 \times 438 \mathrm{~cm}$. Haags Historisch Museum, The Hague, inv. no. 1862-0006-SCH (artwork in the public domain)

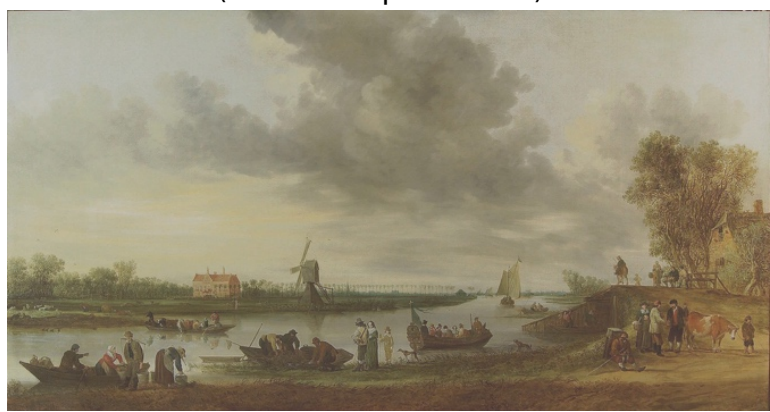

Fig. 7 Jan van Goyen, View of the River Vliet at Voorschoten with House Oostbos, 1642 , oil on canvas, $131.5 \times 252.5 \mathrm{~cm}$. Museum de Lakenhal, Leiden, inv. no. B 1431, on loan from Rijksdienst voor het Cultureel Erfgoed (artwork in the public domain)

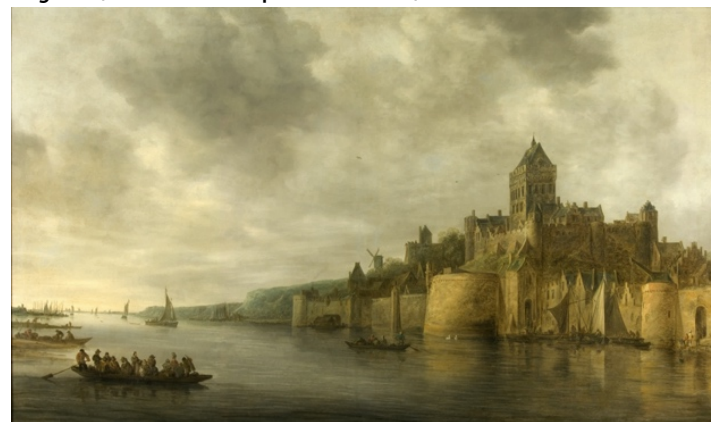

Fig. 8 Jan van Goyen, View of the Valkhof Castle, 1641, oil on canvas, $154 \times 258 \mathrm{~cm}$. Museum het Valkhof, Nijmegen, inv. no. XVI 6 (artwork in the public domain) 


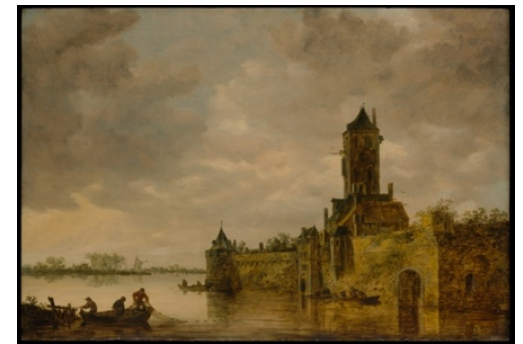

Fig. 9 Jan van Goyen, Castle by a River, 1647, oil on panel, 66 x 97.2 cm. Metropolitan Museum of Art, New York, inv. no. 64.65.1 (artwork in the public domain)

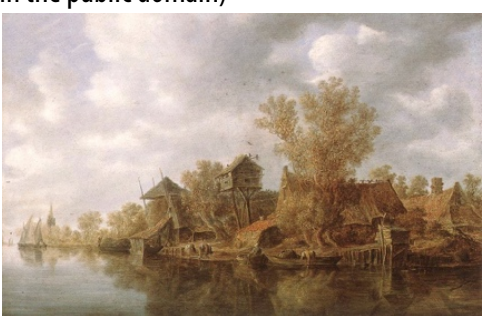

Fig. 10 Jan van Goyen, River View, 1636, oil on panel, 39 × $60 \mathrm{~cm}$. Alte Pinakothek, Munich, inv. no. 4893 (artwork in the public domain)

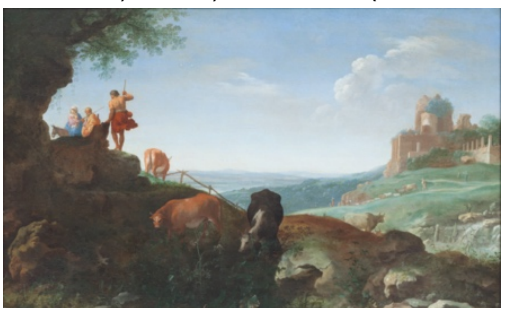

Fig. 11 Cornelis van Poelenburch, Landscape with the Flight into Egypt, 1625 , oil on canvas, $48.2 \times 71.1 \mathrm{~cm}$. Centraal Museum, Utrecht, inv. no. 8391 (artwork in the public domain)

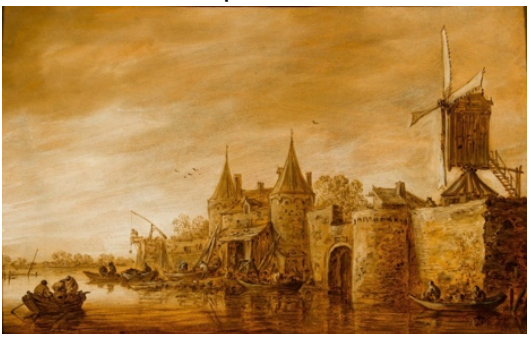

Fig. 12 Jan van Goyen, Fortified Town at a River, 1651, oil on paper mounted on panel, $25.5 \times 41$ cm., P. de Boer, Amsterdam, 2015 (artwork in the public domain)

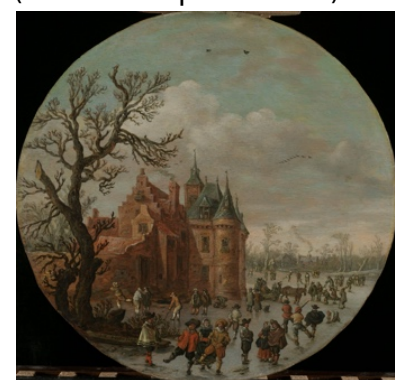

Fig. 13 Jan van Goyen, Winter, 1625, oil on panel, $33.4 \mathrm{~cm}$ diam. Rijksmuseum, Amsterdam, inv. no. SK-A-3946 (artwork in the public domain)

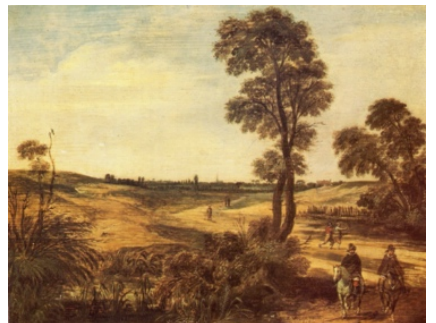

Fig. 3a Esaias van de Velde, Two Horsemen in a Dune Landscape (fig. 3)

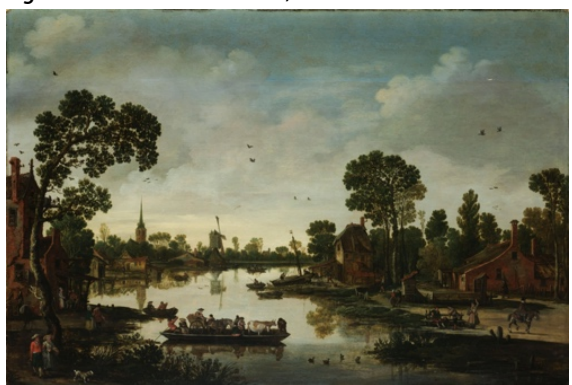

Fig. 14 Esaias van de Velde, The Cattle Ferry, 1622, oil on panel, $75.5 \mathrm{x}$ $113 \mathrm{~cm}$. Rijksmuseum, Amsterdam, inv. no. SK-A-1293 (artwork in the public domain)

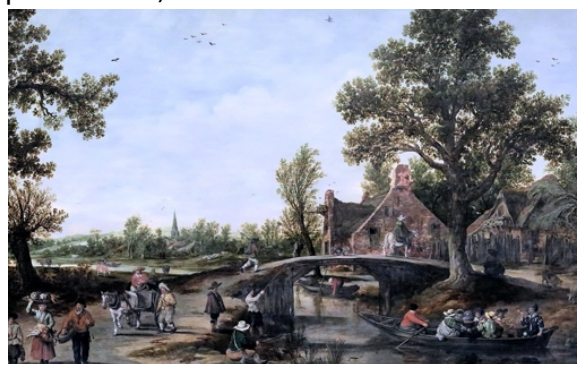

Fig. 15 Jan van Goyen, Village View, 1625, oil on panel, 78 x $124 \mathrm{~cm}$. Kunsthalle, Bremen, inv. no. 48-1826/99 (artwork in the public domain)

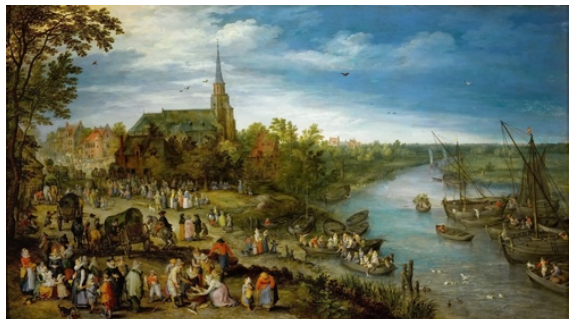

Fig. 16 Jan Brueghel the Elder, Parish Fair in Schelle, 1614, oil on panel, $52 \times 90.5 \mathrm{~cm}$. Kunsthistorisches Museum, Vienna, inv. no. GG 9102 (artwork in the public domain)

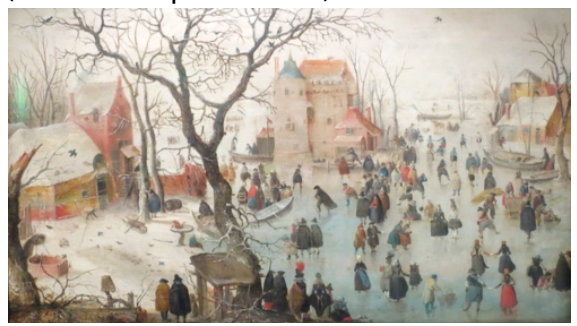

Fig. 17 Hendrick Avercamp, Winter Landscape with Skaters near a Castle, 1608, oil on panel, $33 \times 55.5 \mathrm{~cm}$. Bergen Art Museum, Bergen (artwork in the public domain) 


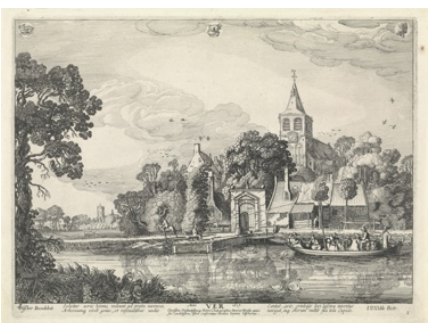

Fig. 18 Jan van de Velde II, Ver (Spring) from the Four Seasons series, 1671, etching on paper, $26.8 \times 35.8 \mathrm{~cm}$. Rijksmuseum, Amsterdam (artwork in the public domain)

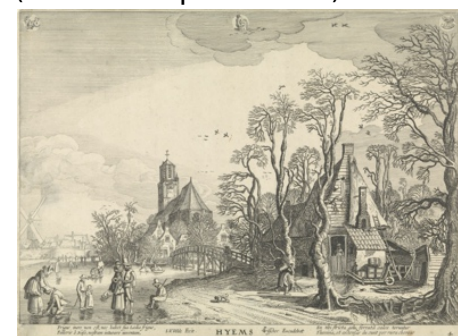

Fig. 19 Jan van de Velde ll, Hyems (Winter) from the Four Seasons series, 1671, etching on paper, $26.8 \times 35.8 \mathrm{~cm}$. Rijksmuseum, Amsterdam (artwork in the public domain)

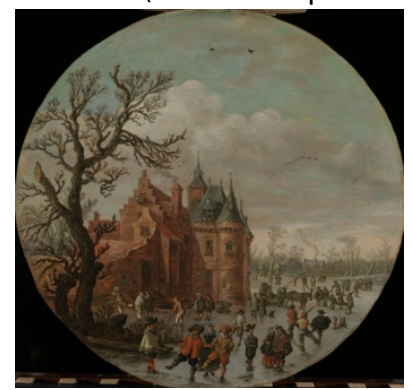

Fig. 13a Jan van Goyen, Winter, 1625 (fig. 13)

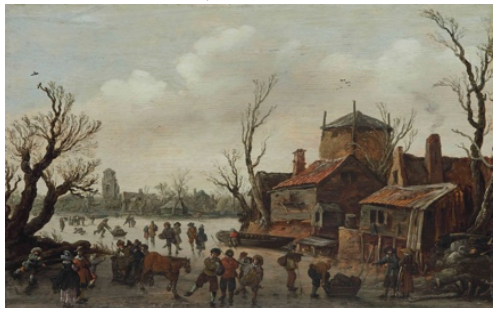

Fig. 20 Jan van Goyen, Winter Landscape, 1626, oil on panel, $32.5 \times 50$ $\mathrm{cm}$. Christie's, New York, sale of June 4, 2014, lot 6 (artwork in the public domain)

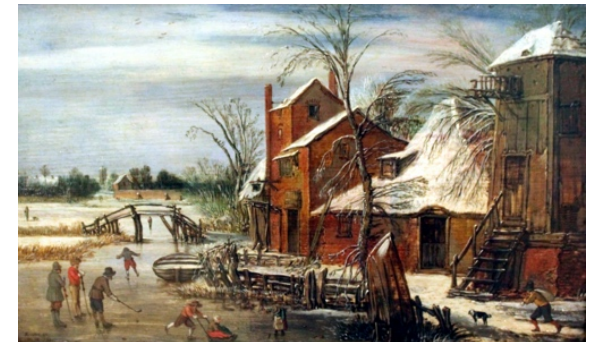

Fig. 21 Esaias van de Velde, Winter Landscape, 1615, oil on panel, $28 \mathrm{x}$ $46 \mathrm{~cm}$. Museum der bildenden Künste, Leipzig (artwork in the public domain)

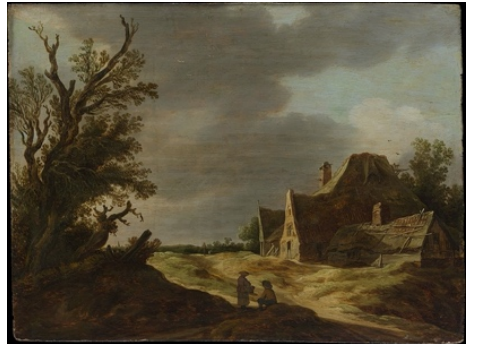

Fig. 22 Jan van Goyen, Sandy Road with a Farmhouse, 1627, oil on panel, 30.8 x $41.3 \mathrm{~cm}$. Metropolitan Museum of Art, New York, inv. no. 1972.25 (artwork in the public domain)

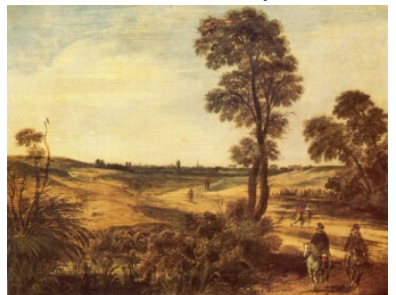

Fig. 3b Esaias van de Velde, Two Horsemen in a Dune Landscape (fig. 3)

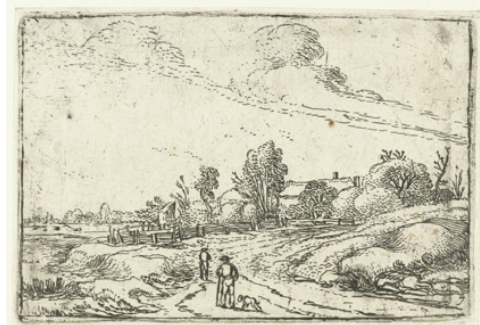

Fig. 23 Esaias van de Velde, Road through the Dunes, ca. 1614, etching on paper, $6.9 \times 10.2 \mathrm{~cm}$. Rijksmuseum, Amsterdam (artwork in the public domain)

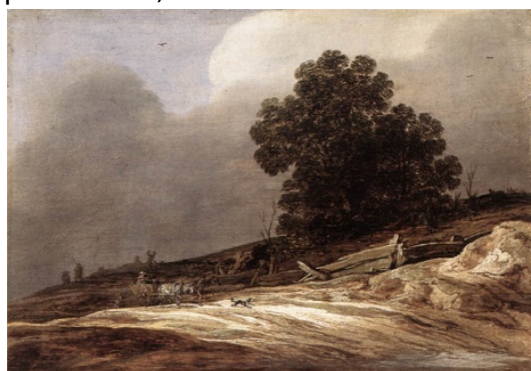

Fig. 24 Pieter de Molijn, Dune Landscape with Trees and Wagon, 1626, oil on panel, $26 \times 36 \mathrm{~cm}$. Herzog Anton Ulrich-Museum, Braunschweig, inv. no. 338 (artwork in the public domain)

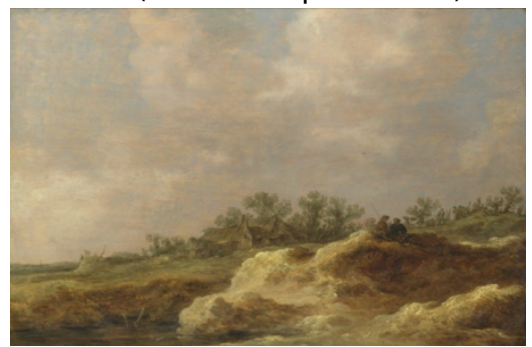

Fig. 25 Jan van Goyen, Cottage on a Heath, ca. 1629, oil on panel, 39.7 x $60.5 \mathrm{~cm}$. National Gallery, London, inv. no. NG 137 (artwork in the public domain) 


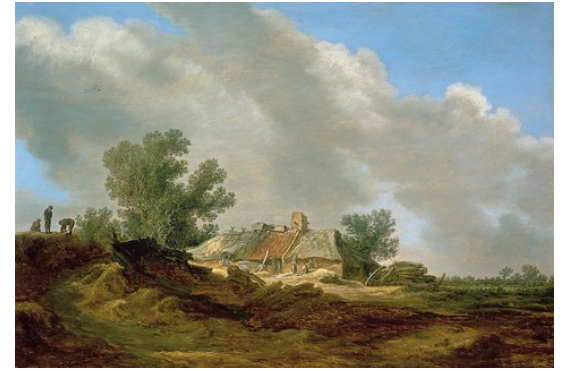

Fig. 26 Jan van Goyen, Dune Landscape with Cottage and Figures, 1629, oil on panel. Carmen Thyssen-Bornemisza Collection on loan at the Museo Nacional Thyssen-Bornemisza, Madrid, inv. no. CTB.1994.22 (artwork in the public domain)

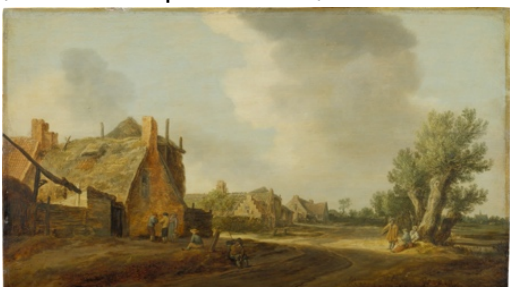

Fig. 27 Jan van Goyen, Village Street with Peasants, 1628, oil on panel, $35.7 \times 63 \mathrm{~cm}$. Städel Museum, Frankfurt, inv. no. SG 1236 (artwork in the public domain)

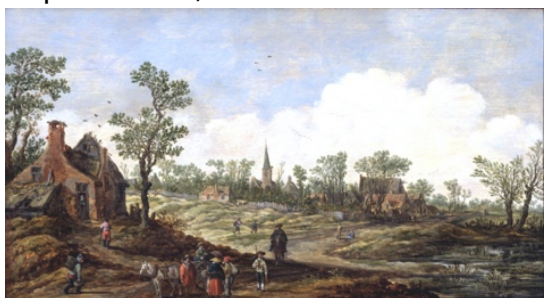

Fig. 28 Jan van Goyen, Landscape with a Village View, 1626, oil on panel, $32 \times 59 \mathrm{~cm}$. Museum de Lakenhal, Leiden, inv. no. $\$ 860$ (artwork in the public domain)

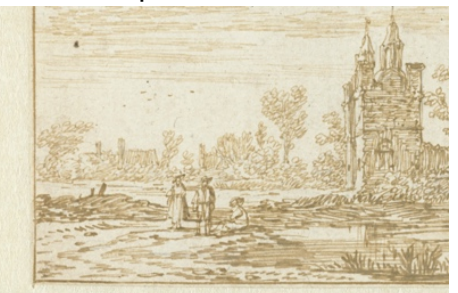

Fig. 29 Jan van Goyen, Landscape with View of a Castle, 1624, pen and brown ink on paper, $5.3 \times 8.8 \mathrm{~cm}$. Rijksmuseum, Amsterdam, inv. no. RP-T-1899-A-4317 (artwork in the public domain)

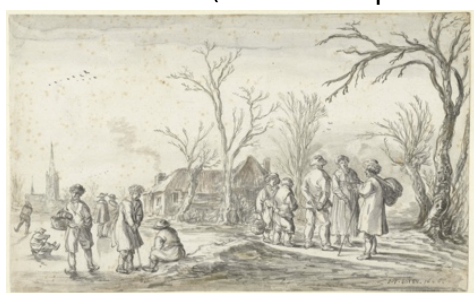

Fig. 30 Jan van Goyen, Village with Figures in Winter, 1626, brush and gray, brown, blue, and gray-green ink with black chalk on paper, 19.4 x $32 \mathrm{~cm}$. Rijksmuseum, Amsterdam, inv. no. RP-T-1902-A-4701 C (artwork in the public domain)

JHNA 13.2 (Summer 2021)

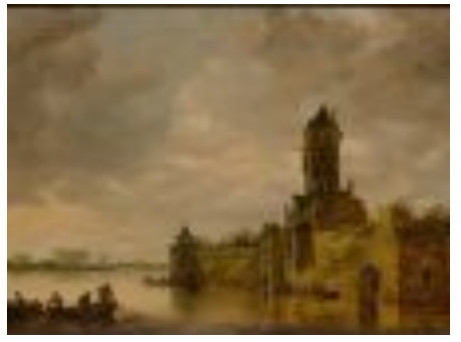

Fig. 9a Jan van Goyen, Castle by a River (fig. 9)

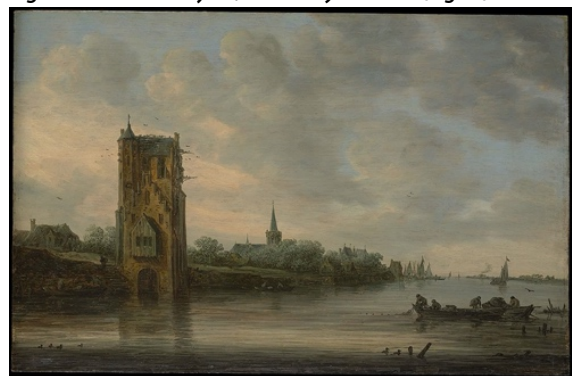

Fig. 31 Jan van Goyen, The Pelkus Gate near Utrecht, 1646, oil on panel, $36.8 \times 57.2 \mathrm{~cm}$. Metropolitan Museum of Art, New York, inv. no. 45.146.3 (artwork in the public domain)

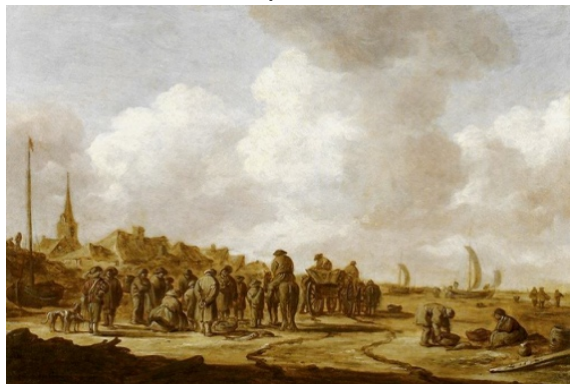

Fig. 32 Jan van Goyen, Selling Fish at the Beach of Scheveningen, 1632, oil on panel, $29.5 \times 43 \mathrm{~cm}$. Museum der bildenden Künste, Leipzig, inv. no. 235 (artwork in the public domain)

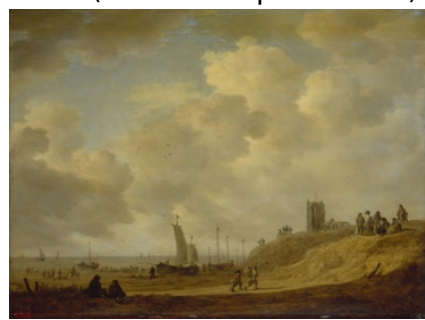

Fig. 33 Jan van Goyen, The Shore at Egmond-at-See, 1645, oil on panel, $54 \times 72 \mathrm{~cm}$. State Hermitage Museum, Saint Petersburg, inv. no. GZ993 (artwork in the public domain)

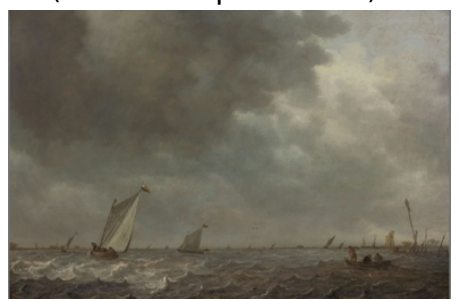

Fig. 34 Jan van Goyen, Sailing Vessels on a Lake, 1639, oil on panel, 47 $x 70 \mathrm{~cm}$. Museum Boijmans van Beuningen, Rotterdam, inv. no. VdV 32 (artwork in the public domain) 


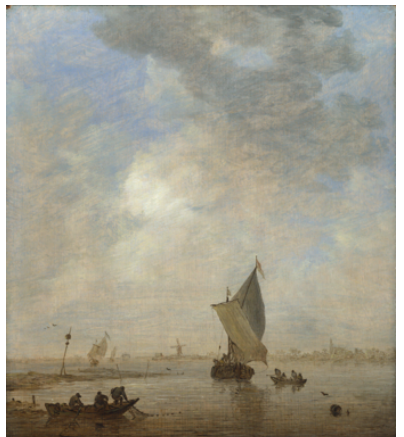

Fig. 35 Jan van Goyen, A River Scene with Fishermen Hauling a Net, 1640-45, oil on panel, 37 x $33 \mathrm{~cm}$. National Gallery, London, inv. no. NG6155 (artwork in the public domain)

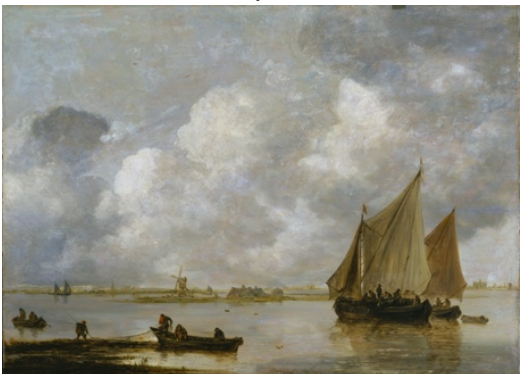

Fig. 36 Jan van Goyen, Ships on the Haarlemmermeer, 1656, oil on panel, $40.5 \times 55.5 \mathrm{~cm}$. Städel Museum, Frankfurt, inv. no. SG 1071 (artwork in the public domain)

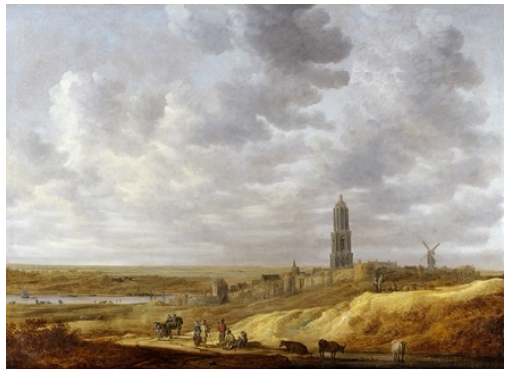

Fig. 37 Jan van Goyen, Extensive Landscape with View of Rhenen, 1636, oil on panel, $101 \times 136.5 \mathrm{~cm}$. Private collection (artwork in the public domain)

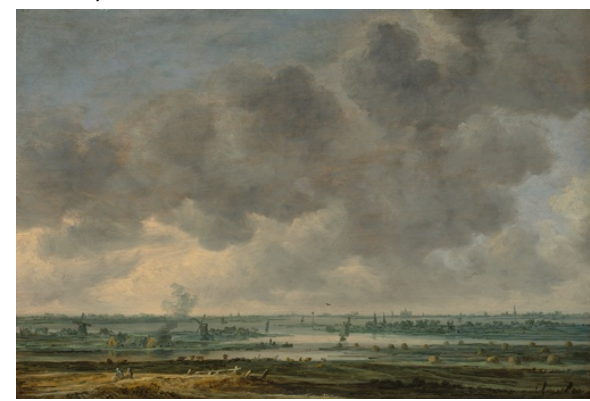

Fig. 38 Jan van Goyen, View of Haarlem and the Haarlemmermeer, 1646, oil on panel, $34.6 \times 50.5 \mathrm{~cm}$. Metropolitan Museum of Art, New York, inv. no. 71.62 (artwork in the public domain)

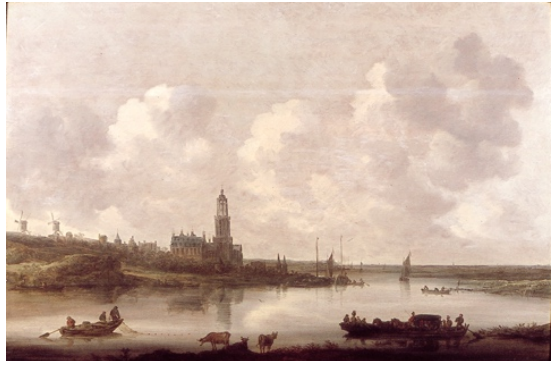

Fig. 39 Jan van Goyen, View of the River Rhine near Rhenen, 1646, oil on panel, $66 \times 98 \mathrm{~cm}$. Rijksdienst voor het Cultureel Erfgoed, inv. no. NK2710 (artwork in the public domain)

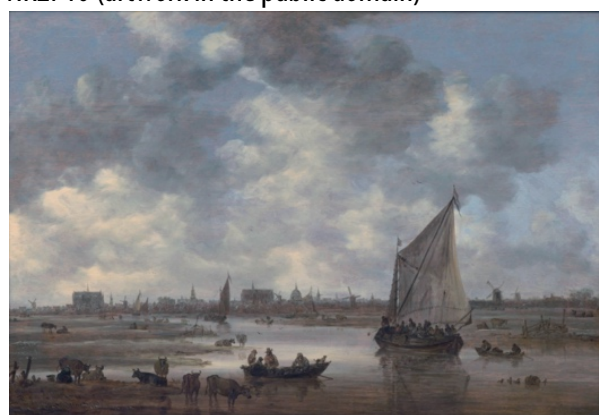

Fig. 40 Jan van Goyen, View of Leiden from the Northeast, 1650, oil on panel, $66.5 \times 97.5 \mathrm{~cm}$. Museum de Lakenhal, Leiden, inv. no. S115 (artwork in the public domain)

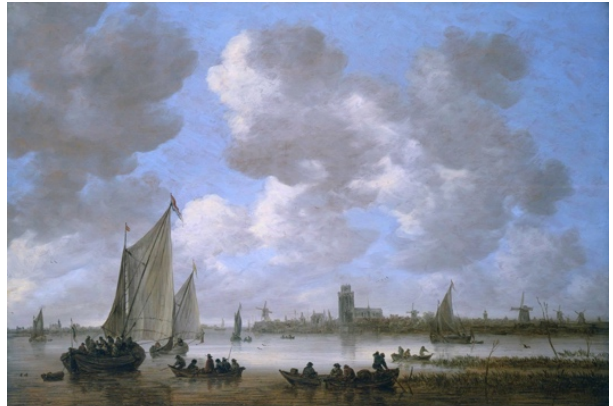

Fig. 41 Jan van Goyen, View of Dordrecht, 1651, oil on panel, 67.2 x $98.1 \mathrm{~cm}$. Dordrechts Museum, Dordrecht, inv. no. DM/008/886 (artwork in the public domain) https://commons. wikimedia.org/w/index.php?curid=1679775

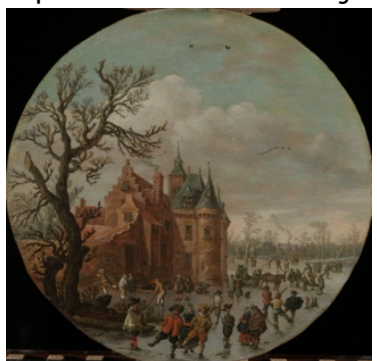

Fig. 13b Jan van Goyen, Winter, 1625 (fig. 13) 


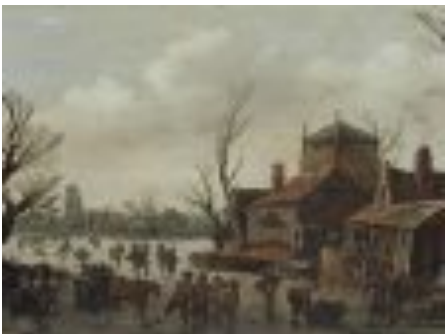

Fig. 20a Jan van Goyen, Winter Landscape (fig. 20)

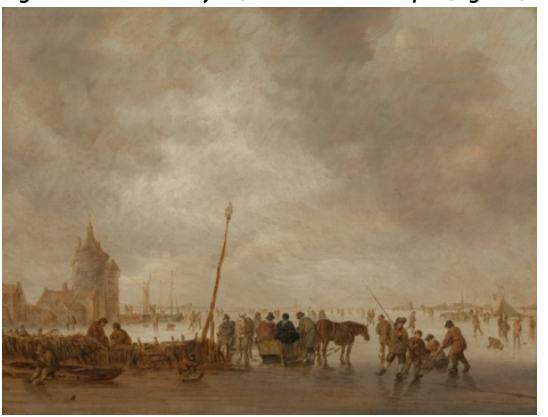

Fig. 42 Jan van Goyen, Frozen River with Skaters, ca. 1641, oil on panel, $35 \times 46 \mathrm{~cm}$. Rijksdienst voor het Cultureel Erfgoed, inv. no. NK2512

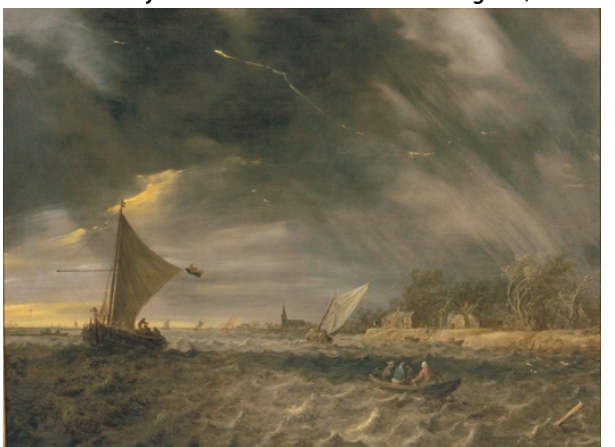

Fig. 43 Jan van Goyen, $A$ Thunderstorm, 1641, oil on canvas, $137.8 \mathrm{x}$ $183.2 \mathrm{~cm}$. Legion of Honor Museum, San Francisco (artwork in the public domain)

https://upload.wikimedia.org/wikipedia/commons/e/ec/Goyen_1641 _The_Thunderstorm.jpg

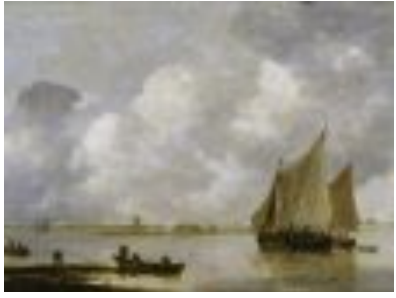

Fig. 36a Jan van Goyen, Ships on the Haarlemmermeer (fig. 36a)

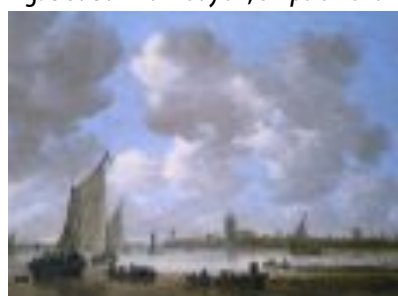

Fig. 41a Jan van Goyen, View of Dordrecht (fig. 41)

\section{Bibliography}

Angel, Philips. Lof der schilder-konst. Leiden, 1642.

Bakker, Boudewijn. "Levenspelgrimage of vrome wandeling? Claes Janszoon Visscher en zijn serie Plaisante Plaetsen." Oud Holland 107 (1993): 97-116.

—. "Nederland naar 't leven: Een inleiding." In Bakker and Leeflang, Nederland naar't leven, 617. 
Bakker, Boudewijn, and Huigen Leeflang. Nederland naar 't leven: Landschapsprenten uit de Gouden Eeuw. Exh. cat. Zwolle and Amsterdam: Waanders and Museum het Rembrandthuis, 1993.

Beck, Hans-Ulrich. Einführung: Katalog der Handzeichnungen. Vol. 1 of Jan van Goyen 15961656: Ein Oeuvreverzeichnis. Amsterdam: A. L. van Gendt, 1972.

-. Jan van Goyen 1596-1656. Exh. cat. London: Richard Green, 1996.

-. Katalog der Gemälde. Vol. 2 of Jan van Goyen 1596-1656: Ein Oeuvreverzeichnis.

Amsterdam: A. L. van Gendt, 1973.

-. Künstler um Jan van Goyen: Maler und Zeichner. Doornspijk: Davaco, 1991.

Beck, Hans-Ulrich, et al. Jan van Goyen, 1596-1656: Conquest of Space; Paintings from Museums and Private Collections (Exh. cat. Amsterdam and Bremen: K. \& V. Waterman and Car. Ed. Schünemann KG, 1981.

Beck, Hans-Ulrich, et al. Jan van Goyen 1596-1656: Poet of the Dutch Landscape; Paintings from Museums and Private Collections in Great Britain. Exh. cat. London: Alan Jacobs Gallery, 1977.

Biesboer, Pieter. Collections of Paintings in Haarlem 1572-1745. Vol. 1 of Netherlandish Inventories. Documents for the History of Collecting. Malibu: The Getty Research Institutes, 2001.

\{Boers-Goosens, Marion E. "Een nieuwe markt voor kunst. De expansie van de Haarlemse schilderijenmarkt in de eerste helft van de zeventiende eeuw." In "Kunst voor de markt/Art for the Market 1500--700," ed. Reindert Falkenburg et al. Special issue, Nederlands Kunsthistorisch Jaarboek 50 (1999): 194-219.\}

\{Bok, Marten Jan. "Pricing the Unpriced: How Dutch Seventeenth-Century Painters Determined the Selling Price of Their Work." In Urban Achievement in Early Modern Europe: Golden Ages in Antwerp, Amsterdam and London, edited by Patrick O'Brian et al., 186-209. Cambridge: Cambridge University Press, 2001.\}

-. "Vraag en aanbod op de Nederlandse kunstmarkt, 1580-1700." PhD diss., Utrecht University, 1994.

Bol, Laurens J. Holländische Maler des 17: Jahrhunderts nahe der großen Meistern. München: Klinkhardt \& Biermann, 1982.

Bomford, David. "Techniques of the Early Dutch Landscape Painters." In Dutch Landscape: The Early Years, Haarlem and Amsterdam 1590-1650, edited by Christopher Brown, 45-56. Exh. cat. London: National Gallery Publications, 1986. 
Bredius, Abraham. “Jan Josephszoon van Goyen: Nieuwe bijdragen tot zijne biographie.” Oud Holland 14 (1896): 113-25.

—. Künstler-Inventare. 7 vols. The Hague: Martinus Nijhoff, 1915-1922.

—. "De schilder Johannes van de Capelle." Oud Holland 10 (1892): 26-40.

Briels, Jan G. C. A. Vlaamse schilders in de Noordelijke Nederlanden in het begin van de Gouden Eeuw. Haarlem: Becht, 1987.

\{Broekman, Inge. “Constantijn Huygens, de kunst en het hof.” PhD diss., University of Amsterdam, 2010.\}

Buijsen, Edwin. The Sketchbook of Jan van Goyen from the Bredius-Kronig Collection. The Hague: Foundation Bredius Genootschap, 1993.

Chong, Alan. “The Market for Landscape Painting in Seventeenth-Century Holland.” In Masters of 17th-Century Dutch Landscape Painting, edited by Peter Sutton, 104-20. Exh. cat. Boston: Museum of Fine Arts, 1987.

De Marchi, Neil, and Hans J. Van Miegroet. “Art, Value and Market Practices in the Netherlands in the Seventeenth Century." Art Bulletin 76 (1994): 451-64.

-. 'Pricing Invention: 'Originals', 'Copies' and their Relative Value in Seventeenth-Century Netherlandish Art Markets." In Recent Contributions to the Economics of the Arts, edited by Victor Ginsburgh and Pierre-Michel Menger, 27-70. Amsterdam: Elsevier Science, 1996.

Drossaers, S. W. A. and T. H. Lunsingh Scheurleer. Inventarissen van de inboedels in de verblijven van de Oranjes en daarmede gelijk te stellen stukken 1567-1795. 3 vols. The Hague: Martinus Nijhoff, 1974-1976.

Dumas, Charles. Haagse stadsgezichten 1550-1800: Topografische schilderijen van het Haags Historisch Museum. Zwolle: Waanders, 1991.

Emmens, Jan A. Rembrandt en de regels van de kunst. Amsterdam: C. A. van Oorschot, 1979.

\{Falkenburg, Reindert L. “'Schilderachtig weer' bij Jan van Goyen.” In Jan van Goyen, edited by Christiaan Vogelaar, 60-69. Exh. cat. Zwolle and Leiden: Waanders and Stedelijk Museum de Lakenhal, 1996.\}

\{-. "Onweer bij Jan van Goyen: Artistieke wedijver en de markt voor het Hollandse landschap in de 17de eeuw." In "Natuur en landschap in de Nederlandse kunst 1500-1800/Nature and Landscape in Netherlandish Art 1500-1800," edited by Reindert Falkenburg et al. Special issue, Nederlands Kunsthistorisch Jaarboek/Netherlands Yearbook for History of Art 48 (1997): 116-61.\} 
Floerke, Hans. Studien zur Niederländischen Kunst- und Kulturgeschichte: Die Formen des Kunsthandels, das Atelier und die Sammler in den Niederlanden vom 15.-18. Jahrhundert. Munich and Leipzig: Georg Müller, 1905.

Fock, C. Willemijn. "Kunstbezit in Leiden in de 17de eeuw.” In Lunsing Scheurleer, Fock, and van Dissel, eds., Het Rapenburg, 5:3-33. \{English version: C. Willemijn Fock,. "Art Ownership in Leiden in the Seventeenth Century," translated by Anne Baudouin. Journal of Historians of Netherlandish Art 13, no. 1 (Winter 2021), https://doi.org/10.5092/jhna.2021.13.1.4.\}

Getty Research Institute. The Getty Provenance Index Databases, https://www.getty.edu/research/tools/provenance/search.html.

Gifford, E. Melanie. “Jan van Goyen en de techniek van het naturalistisch landschap.” In Jan van Goyen, edited by Christiaan Vogelaar, 70-81. Exh. cat. Zwolle and Leiden: Waanders and Stedelijk Museum de Lakenhal, 1996.\}

—. "Style and Technique in Dutch Landscape Painting in the 1620s." In Preprints: Historical Painting Techniques, Materials and Studio Practice, edited by Arie Wallert, Erma Hermsen, and Marja Peek, 140-47. Leiden and Malibu: Getty Conservation Institute, 1995.

Haak, Bob. The Golden Age: Dutch Panting of the Seventeenth Century. New York: Harry N. Abrams, 1984.

Hoogstraten, Samuel van. Inleyding tot de hooge schoole der schilderkonst: Anders de zichtbaere werelt. Rotterdam, 1678.

Houbraken, Arnold. De groote schouburgh der Nederlantsche konstschilders en schilderessen. 3 vols. The Hague, 1753. First published 1718-1721.

Huygens, Constantijn. De jeugd van Constantijn Huygens door hemzelf beschreven. Translated from the Latin by A. H. Kan. Rotterdam: Ad. Donker, 1971.

\{Israel, Jonathan I. “Adjusting to Hard Times: Dutch Art During its Period of Crisis and Restructuring (c. 1621-1645).” Art History 20 (1997): 449-76.\}

\{Jager, Angela. “'Everywhere illustrious history paintings that are a dime a dozen': The Mass Market for History Painting in Seventeenth-Century Amsterdam." Journal of Historians of Netherlandish Art 7, no. 1 (Winter 2015), https://doi.org/10.5092/jhna.2015.7.1.2.\}

\{-. The Mass Market for History Paintings in Seventeenth-Century Amsterdam: Production, Distribution and Consumption. Amsterdam: Amsterdam University Press, 2020.\}

Jager, Ronald de. "Meester, leerjongen, leertijd: Een analyse van zeventiende-eeuwse NoordNederlandse leerlingcontracten van kunstschilder, goud- en zilversmeden." Oud Holland 104 (1990): 69-111. 
Lairesse, Gerard de. Groot Schilderboek. Haarlem: Johannes Marshoorn, 1740. Written in 1707.

Leeflang, Huigen. "Het landschap in boek en prent: Perceptie en interpretatie van vroeg zeventiende-eeuwse Nederlandse landschapsprenten." In Bakker and Leeflang, Nederland naar 't leven, $18-32$.

-. "Het aardse paradijs: Het Haarlemse landschap in 16de en 17de-eeuwse literatuur en beeldende kunst." In De trots van Haarlem: Promotie van een stad in kunst en historie, edited by Koos Levy-Van Halm et al., 116-34. Exh. cat. Gent: Snouck-Ducaju Snouck-Ducaju in collaboration with the Frans Hals Museum and Teylers Museum, Haarlem, 1995

\{-. "Dutch Landscape: The Urban View; Haarlem and its Environs in Literature and Art, 15th 17th century." In Falkenburg et al., ed., "Natuur en landschap in de Nederlandse kunst 15001800:" 52-115.\}

Lunsingh Scheurleer, Theo H., C. Willemijn Fock, and Albert J. van Dissel, eds. Het Rapenburg: Geschiedenis van een Leidse gracht. 6 vols. Leiden: Rijksuniversiteit Leiden, 1986-1992.

Mander, Karel van. Het schilder-boeck. Haarlem, 1603-1604.

Martin, Wilhelm. De Hollandse schilderkunst in de zeventiende eeuw. 2 vols. Amsterdam: Meulenhoff, 1935-1936.

Miedema, Hessel. De archiefbescheiden van het St. Lucasgilde te Haarlem. 2 vols. Alphen aan de Rijn: Canaletto, 1980.

Miedema, Hessel, ed. Karel van Mander: Het leven de oude antijcke doorluchtighe schilders. Amsterdam: University of Amsterdam, 1981.

\{The Montias Database of 17th Century Dutch Art Inventories, The Frick Collection, https://research.frick.org/montias.\}

Montias, John Michael. “Art Dealers in Seventeenth-Century Netherlands.” Simiolus 18 (1988): $244-56$.

-. Artists and Artisans in Delft: A Socio-Economic Study of the Seventeenth Century. Princeton, NJ: Princeton University Press, 1982.

\{-. “Artists Named in Amsterdam Inventories, 1607-1680," Simiolus 31, no. 4 (2004-2005): $322-47$.

-. "Bramer's Patrons and Clients in Delft." In Jane ten Brink-Goldsmith et al, Leonaert Bramer 1596-1674: Ingenious Painter and Draughtsman in Rome and Delft, 35-46. Exh. cat. Zwolle and Delft: Waanders and Stedelijk Museum Prinsenhof, 1994. 
-. "Cost and Value in Seventeenth-Century Dutch Art." Art History 10 (1987): 455-86.

-. "Estimates of the Number of Dutch Masters, their Earnings and the Output in 1650." Leidschrift 6, no. 3 (1990): 59-74.

—. “The Influence of Economic Factors on Style." De Zeventiende Eeuw 6, no. 1 (1990): 49-57.

-. "Works of Art in Seventeenth-Century Amsterdam: An Analysis of Subjects and Attributions." In Art in History/History in Art: Studies in Seventeenth-Century Dutch Culture, edited by David Freedberg and Jan de Vries, 331-72. Santa Monica: Getty Center for the History of Art and the Humanities, 1991.

Orlers, Jan. Beschrijvinge der Stadt Leyden. Leiden, 1641.

\{Plas, Piet van der, and Martine van der Wielen-de Goede. "Roucoop of Oostbos? Gezicht op de Vliet door Jan van Goyen.” Leids Jaarboekje 107 (2015): 119-34.\}

Karel Porteman. "Zeventiende-eeuwse dichters in last." In Brekende spiegels: Beeldveranderingen in de Nederlandse literatuur, edited by Dirk de Geest and Marc van Vaeck, 43-57. Leuven: Peeters, 1992.

Reznicek, Emile K. J. "Het leerdicht van Karel van Mander en de acribie van Hessel Miedema." Oud Holland 89 (1975): 102-28.

\{Sluijter, Eric Jan. “'All striving to adorne their houses with costly peeces': Two Case Studies of Paintings in Wealthy Interiors." In Art \& Home: Dutch Interiors in the Golden Age, edited by Mariët Westermann, 102-27. Exh. cat. Denver and Zwolle: Denver Art Museum and Waanders, 2001.\}

\{-. "Determining Value on the Art Market in the Golden Age: An Introduction. In Art Market and Connoisseurship: A Closer Look at Paintings by Rembrandt, Rubens and their Contemporaries, edited by Anna Tummers and Koenraad Jonckheere, 7-27. Amsterdam: Amsterdam University Press, 2008.\}

\{-. “'Dien grooten Raphel in het zeeschilderen!' Over de waardering van Jan Porcellis' sobere kunst door eigentijdse kenners." In Liber Amicorum Marijke de Kinkelde: Collegiale bijdragen over landschappen, marines en architectuur, edited by Charles Dumas et al., 343-58. The Hague: Waanders, 2013.\}

—. "De 'heydensche fabulen' in de Noord-nederlandse schilderkunst, circa 1590-1670." PhD diss., Leiden University, 1986.

\{-. De "heydensche fabulen" in de schilderkunst van de Gouden Eeuw: Schilderijen met verhalende onderwerpen uit de klassieke mythologie ca 1590-1670. Leiden: Primavera Pers, 2000.\} 
\{-. "In Praise of the Art of Painting: On Paintings by Gerrit Dou and a Treatise by Philips Angel of 1642." In Eric Jan Sluijter, Seductress of Sight: Studies in Dutch Art of the Golden Age, 198-263. Zwolle: Waanders, 2000.\}

-. De lof der schilderkunst: Over schilderijen van Gerrit Dou (1613-1675) en een traktaat van Philips Angel uit 1642. Hilversum: Verloren, 1993.

\{-. "On Brabant Rubbish: Economic Competition, Artistic Rivalry and the Growth of the Market for Paintings in the First Decades of the Seventeenth Century." Journal of the Historians of Netherlandish Art 1, no. 2 (Summer 2009), https://doi.org/10.5092/jhna.2009.1.2.4. Dutch version: "Over Brabantse vodden, economische concurrentie, artistieke wedijver en de groei van de markt voor schilderijen in de eerste decennia van de zeventiende eeuw," in Nederlands Kunsthistorisch Jaarboek 50 (1999): 113-43.\}

\{-. "Ownership of Paintings in the Dutch Golden Age." In Class Distinctions: Dutch Painting in the Age of Rembrandt and Vermeer, edited by Ronni Baer, 89-111 and 286-91. Exh. cat. Boston: MFA Publications, 2015.\}

\{-. Rembrandt and the Female Nude. Amsterdam: Amsterdam University Press, 2006.\}

\{-. Rembrandt's Rivals: History Painting in Amsterdam, 1630-1650. Amsterdam and Philadelphia: John Benjamins Publishing Company, 2015.\}

- . "Schilders van 'cleyne, subtile ende curieuse dingen': Leidse 'fijnschilders' in contemporaine bronnen." In Leidse fijnschilders: Van Gerrit Dou tot Frans van Mieris de Jonge, 1630-1760, edited by Eric Jan Sluijter, Marlies Enklaar, and Paul Nieuwenhuizen, 15-55. Exh. cat. Zwolle and Leiden: Waanders and Stedelijk Museum de Lakenhal, 1988.

Sluijter-Seijffert, Nicolette C. “Cornelis van Poelenburch (ca. 1593-1667).” PhD diss., Leiden University, 1984.

\{-. Cornelis van Poelenburch, 1594/5-1667: The Paintings. Amsterdam and Philadelphia: John Benjamins Publishing Company, 2016.\}

Smits-Veldt, Mieke. Samuel Coster, ethicus-didacticus: Een onderzoek naar dramatische opzet en morele instructie van Ithys, Polyxena, en Iphigenia. Groningen: Wolters-Noordhoff/Forsten, 1986.

Spiegel, Hendrick Laurenszn. Hart-spieghel. Amsterdam, 1614.

Spies, Marijke. “'Poëetsche fabrijcken' en andere allegorieën eind 16de begin 17de eeuw." Oud Holland 105 (1991): 228-43.

Sutton, Peter. “Introduction.” In Masters of 17th-Century Dutch Landscape Painting, edited by Peter Sutton, 1-63. Exh. cat. Boston: Museum of Fine Art, 1987. 
Stechow, Wolfgang. Dutch Landscape Painting of the Seventeenth Century. London: Phaidon, 1966.

Vogelaar, Christiaan, ed. Jan van Goyen. Exh. cat. Leiden: Zwolle in collaboration with Stedelijk Museum De Lakenhal, 1996.

Vries, Jan de. “Art History.” In Art in History/History in Art: Studies in Seventeenth-Century Dutch Culture; Issues \& Debates, edited by David Freedberg and Jan de Vries, 249-82. Santa Monica: Getty Center for the History of Art and the Humanities, 1991.

Waal, Henri van de. Jan van Goyen. Amsterdam: H. J. W. Becht, 1941.

Weststeijn, Thijs. The Visible World. Samuel van Hoogstraten's Art Theory and the Legitimation of Painting in the Dutch Golden Age. Amsterdam: Amsterdam University Press, 2008.

Wetering, Ernst van de. "Leidse schilders achter de ezel." In Geschildert tot Leyden anno 1626, edited by Maarten Wurfbain et al., 21-31. Exh. cat. Leiden: Stedelijk Museum de Lakenhal, 1976. \{English version: "The Creation of a Pictorial Idea," in Ernst van de Wetering, Rembrandt: The Painter at Work, 74-89. Amsterdam: Amsterdam University Press, 1997.\}

- "Rembrandt's Method: Technique in the Service of Illusion." In Rembrandt: The Master and His Workshop; Paintings, edited by Christopher Brown, Jan Kelch, and Pieter van Thiel, 12-39. New Haven and London: Yale University Press and the National Gallery, London, in collaboration with Gemäldegalerie SMPK, Berlin,and Rijksmuseum, Amsterdam, 1991.

- " "De paletten van Rembrandt en Jozef Israels, een onderzoek naar de relatie tussen stijl en schildertechniek." Oud Holland 107 (1993): 137-51. \{English version: “The Palette: On the Relationship between Style and Painting Technique," in Van de Wetering, Rembrandt: The Painter at Work, 132-53.\}

Willigen, Adriaan van der. Geschiedkundige aantekeeningen over Haarlemsche schilders en andere beoefenaren van de beeldende kunsten. Haarlem: Erven F. Bohn, 1866.

Wurfbain, Maarten, et al. Geschildert tot Leyden anno 1626. Exh. cat. Leiden: Stedelijk Museum de Lakenhal, 1976.

\section{Endnotes}

Unless otherwise stated, the translations are those of the author.

1. Constantijn Huygens, De jeugd van Constantijn Huygens door hemzelf beschreven, trans. A. H. Kan (Rotterdam: Ad. Donker, 1971), 73. The autobiography was written between 1629 and 1631 \{[Huygens wrote the paragraphs on the art of painting in the first months of 1631; 
see Inge Broekman, Constantijn Huygens: De kunst en het hof" (PhD diss., University of Amsterdam, 2010), 179.\}

2. Huygens, De jeugd, 73 .

3. In this respect, Huygens's connoisseurship apparently had little influence at the Stadholder's court. Cornelis van Poelenburch was highly appreciated at the court (as, somewhat less so, was Moyses van Uyttenbroeck), while Van Goyen is not included in the collections of Frederik Hendrik and Amalia van Solms. See Sophia W. A. Drossaers and Th. $\mathrm{H}$. Lunsingh Scheurleer, Inventarissen van de inboedels in de verblijven van de Oranjes en daarmede gelijk te stellen stukken 1567-1795 (The Hague: Martinus Nijhoff, 1974-1976), vol. 1. On the other hand, Van Goyen must have received a commission from the court to paint a country house of the stadholder (see n. 81).

4. Huygens, De jeugd, 72.

5. On the chimney depicted in Thomas de Keyser's portrait of Huygens from 1627 (National Gallery, London), we glimpse the corner of a painting that seems to be a seascape by Porcellis; Huygens appears to present himself in this portrait as a man of advanced taste. \{On the high regard in which Porcellis was held by connoisseurs, see Eric Jan Sluijter, "Dien grooten Raphel in het zeeschilderen!' Over de waardering van Jan Porcellis' sobere kunst door eigentijdse kenners," in Liber Amicorum Marijke de Kinkelder: Collegiale bijdragen over landschappen, marines en architectuur, ed. Charles Dumas et al. (The Hague: Waanders, 2013), 343-58.\}

6. See, for example, H. van de Waal, Jan van Goyen (Amsterdam: H. J. W. Becht, 1941), 49; and Hans-Ulrich Beck, Jan van Goyen 1596-1656: Ein Oeuvreverzeichnis (Amsterdam: A. L. van Gendt 1972), 1:16 and 19. Beck repeated this claim several times, as, for example, in Hans-Ulrich Beck et al., Jan Van Goyen, 1596-1656: Conquest of Space; Paintings from Museums and Private Collections, exh. cat. (Amsterdam and Bremen: K.\&V. Waterman and Car. Ed. Schünemann KG, 1981), 11; and Hans-Ulrich Beck, Jan van Goyen 1596-1656, exh. cat. (London: Richard Green, 1996), n.p.

7. Van de Waal, Jan van Goyen, 52.

8. About Orlers and the shaping of the canon by city descriptions, see Eric Jan Sluijter, De lof der schilderkunst: Over schilderijen van Gerrit Dou (1613-1675) en een traktaat van Philips Angel uit 1642 (Hilversum: Verloren, 1993), 11-14. \{English translation: Eric Jan Sluijter, "In Praise of the Art of Painting: On Paintings by Gerrit Dou and a Treatise by Philips Angel of 1642," in Eric Jan Sluijter, Seductress of Sight: Studies in Dutch Art of the Golden Age (Zwolle: Waanders, 2000), 201-5.\}

9. Jan Orlers, Beschrijvinge der Stadt Leyden (Leiden, 1641), 352.

10. Orlers, Beschrijvinge, 373.

11. For a description of these technical changes, see E. Melanie Gifford, "Style and Technique in Dutch Landscape Painting in the 1620s," in Preprints: Historical Painting Techniques, Materials and Studio Practice, ed. Arie Wallert, Erma Hermsen, and Marja Peek (Leiden and Malibu: Getty Conservation Institute, 1995). \{See also E. Melanie Gifford, “Jan van Goyen en de techniek van het naturalistisch landschap," in Jan van Goyen, ed. Christiaan Vogelaar, 70-79, exh. cat. (Zwolle and Leiden: Waanders and Stedelijk Museum de Lakenhal, 1996).\} 
12. Samuel van Hoogstraten, Inleyding tot de hooge schoole der schilderkonst: Anders de zichtbaere werelt (Rotterdam, 1678), 237.

13. Hans Floerke, Studien zur Niederländischen Kunst- und Kulturgeschichte: Die Formen des Kunsthandels, das Atelier und die Sammler in den Niederlanden vom 15.-

18. Jahnhundert (Munich and Leipzig: Georg Müller, 1905), 19-20. With an advance payment of thirty-two guilders and thereafter fifteen guilders per week, he had to makewith help of a pupil - two paintings every week for twenty weeks. The profit, after deducting forty guilders for pigments and four guilders for every panel, would be shared equally. \{This has often been cited as a sign of the miserable financial situation of a painter who had to work "on the galley," but in fact it was not at all a poor arrangement; see Sluijter, "Dien grooten Raphel in het zeeschilderen," 346-47.\}

14. John Michael Montias, "Cost and Value in Seventeenth-Century Dutch Art," Art History 10 (1987): 455-86, expanded on-especially with regard to rapid, "'monochrome' painting"in John Michael Montias, "The Influence of Economic Factors on Style," De Zeventiende Eeuw 6, no. 1 (1990): 49-57. On the explosive growth of the number of painters in this period, see Jan de Vries, "Art History," in Art in History/History in Art: Studies in Seventeenth-Century Dutch Culture; Issues \& Debates, ed. David Freedberg and Jan de Vries (Santa Monica: Getty Center for the History of Art and the Humanities, 1991), 256-65. \{For an art-historical explanation of this development, see Eric Jan Sluijter, "On Brabant Rubbish: Economic Competition, Artistic Rivalry and the Growth of the Market for Paintings in the First Decades of the Seventeenth Century," Journal of the Historians of Netherlandish Art 1, no. 2 (Summer 2009), https://doi.org/10.5092/jhna.2009.1.2.4.\}

15. On the concept net (neat) or netticheyt (neatness) that Karel van Mander used in connection with earlier painters such as Jan van Eyck and Lucas van Leyden, see Sluijter, Lof der schilderkunst, 56-65 \{English version: Sluijter, Seductress of Sight, 244-55\}. In my view, Van Goyen's technique falls within the category of what Philips Angel calls a los, wacker en soetvloeyend penceel (a loose, adroit, and smoothly fluent brush): Philips Angel, Lof der schilderkonst (Leiden, 1642), 56. This should not be mistaken for the rouwe (rough) manner that van Mander mentions in connection with Titian, which was pursued by Rembrandt in his later work.

16. See Eric Jan Sluijter, “Schilders van 'cleyne, subtile ende curieuse dingen’: Leidse 'fijnschilders' in contemporaine bronnen," in Leidse fijnschilders: Van Gerrit Dou tot Frans van Mieris de Jonge, 1630-1760, ed. Eric Jan Sluijter, Marlies Enklaar, and Paul Nieuwenhuizen (Zwolle and Leiden: Waanders and Stedelijk Museum de Lakenhal, 1988), 36-37. In addition to the ten paintings he had bought for Christina of Sweden (which were returned to him), Spiering Silvercroon owned several more works by Dou. Moreover, the Leiden burgomaster Johan de Bye owned twenty-seven paintings by Dou, and François de le Boe Sylvius owned ten or eleven.

17. With regard to Poelenburch, Willem Vincent Baron van Wyttenhorst owned no fewer than fifty-seven paintings by his hand, and Frederik Hendrik and Amalia van Solms owned at least nineteen (some of them made in collaboration with Alexander Keirincx or Roelant Savery). See Nicolette C. Sluijter-Seijffert, "Cornelis van Poelenburch (ca. 1593-1667)" (PhD diss., Leiden University, 1984), appendices 2 and 3 \{Enlarged English edition: 
Nicolette C. Sluijter-Seijffert, Cornelis van Poelenburch, 1594/5-1667: The

Paintings (Amsterdam and Philadelphia: John Benjamins, 2016), appendices 2 and 3.\}.

18. The economic market principles of "product differentiation" and "process and product innovation" were first brought forward in this context by John Michael Montias, particularly in "Influence of Economic Factors," 50-52. See also Neil De Marchi and Hans J. Van Miegroet, "Art, Value and Market Practices in the Netherlands in the Seventeenth Century," Art Bulletin 76 (1994): 452-54; and Marten Jan Bok, "Vraag en aanbod op de Nederlandse kunstmarkt, 1580-1700” (PhD diss., Utrecht University, 1994), 116-18.

19. In the RKD's photo documentation classification system, all painters that were considered as belonging to the "school" of a certain artist (not necessarily pupils, but artists working in a related style) were arranged together: Van Goyen-school, Poelenburch-school, Rembrandt-school, Dou-school, Ruisdael-school, Wouwerman-school. This reflects well that those painters can be seen as "market leaders." After the "Rembrandt-school," the "Van Goyen-school" is by far the largest of these groups (twenty-one painters).

20. For instance, see Beck, Jan van Goyen: Oeuvreverzeichnis, 1:16 and 19.

21. See the documents in Beck, Jan van Goyen: Oeuvreverzeichnis, 1:29-36.

22. During the 1640s his debts began to run higher; possibly this financial downturn began with large losses from speculation in tulip bulbs. See Abraham Bredius, "Jan Josephszoon van Goyen: Nieuwe bijdragen tot zijne biographie,” Oud Holland 14 (1896): 113-25. His standard of living and the art with which he surrounded himself becomes clear from some sales: in 1652 his paintings yielded 3,749.9 guilders; in 1654 another 2,812 guilders for paintings and drawings.

23. After his death, some household effects and paintings were sold for $2,415.4$ guilders. He still owned no fewer than six houses, which were sold for 15,670 guilders; altogether these sales totaled a bit more than his debts, which amounted to about 18,000 guilders. Unfortunately, we have no details about the paintings that were sold and whether they comprised a personal collection or his stock as an art dealer.

24. The number of dated paintings in the catalogue of Hans-Ulrich Beck jumps from sixteen in 1639 , to twenty-five in 1640 , to thirty-eight in 1641 , and to fifty-seven in 1642 , with a peak of sixty-seven in 1646. In 1648 it diminishes again to twenty-seven and after that year it remains in the twenties and lower thirtiess, with a sudden peak of sixty-four in 1651 (among which were twenty works of oil on paper) and a sudden low of twelve in 1654; there are again thirty-seven paintings in 1655, and from the year of his death (April 27, 1656) only one painting.

25. On the painter's plea in this poem from Cats's Trouringh (1632), which was cited in full by Philips Angel (Angel, Lof der schilder-konst, 27-30), see Sluijter, Lof der schilderkunst, 24-26 \{English version: Sluijter, Seductress of Sight, 213-15\}.

26. Hessel Miedema, De archiefbescheiden van het St. Lucasgilde te Haarlem (Alphen aan de Rijn: Canaletto, 1980), 232 and 246-53, doc. nos. A120, and 280-81, doc. no. A130a. These documents, interesting in many respects, were cited and analyzed by De Marchi and Van Miegroet, "Art, Value and Market Practices," 485-86. The people who signed were Frans Pietersz. de Grebber, Pieter de Molijn, Frans Hals, Cornelis van Kittensteyn, and Salomon van Ruysdael; the petition comprises a protest against the ban on sales that, according to them, were more to the disadvantage of the ordinary painters ("gemeene schilders") who 
made insignificant (slechte) paintings than of the "excellent masters" (extraordinare meesters), also called "masters who have reached perfection" (meester tot Perfectie gekomen synde). \{See also Marion E. Boers-Goosens, "Een nieuwe markt voor kunst: De expansie van de Haarlemse schilderijenmarkt in de eerste helft van de zeventiende eeuw," in "Kunst voor de markt/Art for the Market 1500-1700," ed. Reindert Falkenburg et al., special issue, Nederlands Kunsthistorisch Jaarboek 50 (1999): 195-200.

27. On art dealers who mainly sold nameless dozijnwerk (works by the dozen) and copies by painters who worked for them, see John Michael Montias, "Art Dealers in SeventeenthCentury Netherlands," Simiolus 18 (1988): 246-53. \{See, on this subject, Angela Jager "Everywhere illustrious history paintings that are a dime a dozen': The Mass Market for History Painting in Seventeenth-Century Amsterdam," Journal of Historians of Netherlandish Art 7, no. 1 (Winter 2015), https://doi.org/10.5092/jhna.2015.7.1.2https://doi.org/10.5092/jhna.2015.7.1.2; and Angela Jager, The Mass Market for History Paintings in Seventeenth-Century Amsterdam: Production, Distribution and Consumption (Amsterdam: Amsterdam University Press, 2020)\}.

28. See Montias, “Art Dealers," 250. For example, average valuation prices of the paintings stock of the art dealers Balkeneynde was 4.1 guilders ( 3.3 guilders for the nameless paintings) and Blaeuw 5.5 guilders (3.9 guilders for nameless paintings).

29. The research by Montias and Fock show that during the course of the century the number of pictures associated with the name of a painter-that is, pictures for which one knew or recognized the maker-rose enormously, culminating in the 1660s (15.4 percent in Delft, 42.4 percent in Leiden). John Michael Montias, Artists and Artisans in Delft: A SocioEconomic Study of the Seventeenth Century (Princeton NJ: Princeton University Press, 1982), 227; C. Willemijn Fock, "Kunstbezit in Leiden in de 17de eeuw," in Het Rapenburg: Geschiedenis van een Leidse gracht, ed. Theo H. Lunsingh Scheurleer, C. Willemijn Fock, and Albert J. van Dissel (Leiden: Rijksuniversiteit Leiden, 1990), 5a:3-33. The considerable difference between the two cities is due to the fact that the Leiden inventories include a selection of inventories of well-to-do people; the number of attributed paintings in such inventories is almost always larger than in more modest ones. After 1670 the number of attributions diminishes. \{For an English translation of Fock's essay: C. Willemijn Fock, “Art Ownership in Leiden in the Seventeenth Century," trans. Anne Baudouin, Journal of Historians of Netherlandish Art 13, no. 1 (Winter 2021), https://doi.org/10.5092/jhna.2021.13.1.4.\}

30. I have consulted inventories of between about 1630 and 1670 (including paintings that had been brought together between approximately 1620 and 1660) that were published in Abraham Bredius, Künstler-Inventare, 7 vols. (The Hague: Martinus Nijhoff, 1915-1922); and the inventories collected in the Getty Provenance Index CD Series, housed at the RKD, in which inventories from Haarlem, Amsterdam, and Utrecht assembled by, respectively, Pieter Biesboer, John Michael Montias, and Marten Jan Bok can be found. Of Pieter Biesboer's Haarlem inventories, about five hundred are in the Getty Provenance Index; the next 2,600 will be included on the second CD. Pieter Biesboer kindly informed me about the paintings found by Van Goyen. \{All of Biesboer's Haarlem inventories are now online in the Getty Research Institute's Provenance Index Databases, 
https://www.getty.edu/research/tools/provenance/search.html. Moreover, Biesboer published the most interesting ones in Pieter Biesboer, Collection of Paintings in Haarlem 1572-1745, vol. 1 of Netherlandish Inventories, Documents for the History of Collecting (Malibu: Getty Research Institute, 2001).\} The Leiden inventories collected by C. Willemijn Fock were also examined (these are the 120 inventories on which Fock, "Kunstbezit Leiden," was based). As far as they relate to people living on the Rapenburg, they have been published in Lunsingh Scheurleer, Fock, and van Dissel, eds., Het Rapenburg; I also consulted some inventories published elsewhere. I wish to thank Pieter Biesboer and Willemijn Fock for making their findings available to me.

31. For example, the Leiden inventories collected and analyzed by Willemijn Fock for her article are a selective sample of twelve inventories every decade that are of special interest because of paintings they contain. The Delft and Haarlem inventories brought together by Montias and Biesboer, respectively, are all the inventories from the Delft and Haarlem notary archives (and orphanage archives) they could find. The Amsterdam inventories collected by Montias are a random sample of inventories in which artists' names are recorded.

32. Fock's selection of inventories for her article contained seventy-nine Van Goyen paintings altogether between 1630 and 1700; Dou is second with forty-eight works (and thirteen copies). However, the fact that twenty-seven of those were in one collection (Joan de Bije), makes this number somewhat distorting. Pieter de Molijn is third, with forty-five paintings (Fock, "Kunstbezit Leiden," 12-14). \{Piet Bakker informed me that the total number of seventeenth-century Leiden inventories assembled by Willemijn Fock is 501, of which 257 include attributions. Sixty-seven of these record works by van Goyen, including a total of 171 paintings attributed to him, including four copies and one drawing.\}

33. Montias, Artists and Artisans in Delft, 256-57.

34. John Michael Montias, "Works of Art in Seventeenth-Century Amsterdam: An Analysis of Subjects and Attributions," in Freedberg and de Vries, Art in History/History in Art, 364-67. During the period 1650-1679, Van Goyen is ex aequo with Lievens in fifth place (twentytwo works in thirteen inventories); in the period before that (1620-1649) he is in twentieth place (ex aequo with another three). In both periods combined, Van Goyen is in sixth place, after Jan Miense Molenaer, Rembrandt, de Momper (works by both Joos and Frans de Momper), Jan Porcellis, and Philips Wouwerman (I did not count D'Hondecoeter, since that number includes three painters of that name). The numbers of the latter four artists differ only slightly, ranging from thirty-seven (De Momper), thirty-six (Porcellis), and thirty-two (Wouwermans) to thirty-one (Van Goyen). A few inventories less or more might shift the numbers considerably; this group of painters, however, seems to be at the top. In a much later article by Montias on Amsterdam inventories, Van Goyen is in eleventh place: John Michael Montias, “Artists Named in Amsterdam Inventories, 16071680," Simiolus 31, no. 4 (2004-2005): 322-47.\}

35. This third place is a provisional estimate by Pieter Biesboer. \{Van Goyen is indeed in third place, with no fewer than seventy-nine paintings; his numbers are the highest of the landscape painters, followed by Pieter de Molijn with seventy paintings and Cornelis Decker with sixty-two. See Pieter Biesboer, Collection of Paintings in Haarlem, 34. 
36. Alan Chong, "The Market for Landscape Painting in Seventeenth-Century Holland," in Masters of 17th-Century Dutch Landscape Painting, ed. Peter Sutton, exh. cat (Boston: Museum of Fine Arts, 1987), 117-18.

37. In Leiden his work is by far the most widely distributed of all the masters; in Fock's selection we find ninety-seven paintings in thirty-four inventories (Fock, "Kunstbezit in Leiden," 12). This is in great contrast to Dou: sixty-one works in twelve inventories. In Amsterdam, too, we find-for example, in Montias's research - thirty-one works by Van Goyen in eighteen inventories, against forty-one by Rembrandt in fourteen inventories and twenty-two by Lievens in five (Montias, "Works of Art in Seventeenth-Century Amsterdam," 364-67).

38. \{Gerard Ypelaer: Erfgoed Leiden \& Omgeving (hereafter "ELO"), Notarial Archives (hereafter "NA") notary (hereafter "not.") D. de Fries, inv. 1230, deed 57, March 22, 1679; it is not entirely clear if he had twelve or even fifteen (!) paintings by Van Goyen; the inventory also includes, among others, three works by Willem van de Velde and two by Pieter Claesz.\} Jan Janszn van Rhijn: ELO, NA not. Outerman, inv. 472, deed 268, April 19, 1668. This inventory also includes, among others, ten works by Van der Claeuw, eight by De Molijn, five by Berchem, and four by Lelyenberch.

39. Henrick Bugge van Ring: ELO, NA not. L. van Swieten, inv. 1005, deed 10, March 30, 1667; Bugge had no fewer than sixty-four paintings in the front room only! This inventory also includes, among others, eighteen works by Brekelenkam; six by van Uyttenbroeck; five each by Steen, Isaac van Swanenburch, and Lelyenbergh; and four by Teniers. \{On this huge collection, see Eric Jan Sluijter, “All striving to adorne their houses with costly peeces': Two Case Studies of Paintings in Wealthy Interiors," in Art \& Home: Dutch Interiors in the Golden Age, ed. Mariët Westermann, exh. cat. (Denver and Zwolle: Denver Art Museum and Waanders, 2001),116-27\}.

40. Gerard van Hoogeveen: ELO, NA not. C. van Berendrecht, inv. 852, deed 34, March 11, 1665); this inventory also includes, among others, nine works by "Fabritius," four by Porcellis, and three each by Molijn and Rembrandt.

41. Jean Francois Tortarolis: ELO, NA not. S. van Swanenburch, inv. 611, deed 124, December 7, 1656; see also Lunsingh Scheurleer, Fock, and van Dissel, eds., Het Rapenburg, 4b:488; this inventory also includes, among others, nine works by Dirck Hals, seven by Porcellis, five by Schilperoort, four by Molijn, and three each by Lievens, Isaac van Ostade, and "Swanenburch," respectively.

42. Jan van Griecken: ELO, NA not. A. Raven, inv. 762, deed 351, August 1657; this inventory also includes, among others, three works by "Palamedes" and two each by Uyttenbroeck, de Vlieger, and van Spreeuwen. \{Sara de Witte: ELO, NA not. J. Stam, inv. 1269, deed 8, June 20, 1673 ; this inventory also includes two works by De Poorter and two by Ostade\}; Le Maire: ELO, NA not. C. Berendrecht, inv. 853, deed 141, October 8, 1666; this inventory also includes, among others, three works by "Hals" and two each by Molijn, de Putter, Van de Venne, and "Veen."

43. Bredius, Künstler-Inventare, 287-91. This landscape painter is only known from documents. There seems to be a Leiden connection here. In addition to Van Goyen and Rembrandt, he also owned work by Pieter de Neyn. 
44. Getty Provenance Index: Johan Bardoel, inventory of 1663, 122 paintings. This inventory also includes, among others, six works by De Grebber, four each by Molijn and Porcellis, and two each by De Hulst, Frans de Momper, and Terborch.

45. Getty Provenance Index: Nicolaes Meyer, inventory of 1663, 154 numbers. This inventory also includes, among others, five works by Bartsius and two each by Aertsen, Moreelse, Lastman, and van Mander.

46. Bredius, Künstler-Inventare, 2141-44 (1658). This is an inventory of both Cornelis Borsman and Joh. van Campen. This inventory also includes three works by de Vlieger and two by Wouwerman.

47. Abraham Bredius, "De schilder Johannes van de Capelle," Oud Holland 10 (1892): 26-40; inventory of 1679, 197 paintings. See also n. 49.

48. This inventory also includes, among others, six works by Frans Hals, five by Segers, and four each by Rembrandt and Brouwer. It should be noted that he owned no fewer than 1,400 drawings by de Vlieger!

49. Both in the Getty Provenance Index: Michiel Barrelebos, 1664, and Bregitta Screvelius, 1657. The latter owned ten paintings.

50. Pieter Bruijningh, 1664, Getty Provenance Index. The other identified paintings in Bruijningh's inventory are two works by Dirck Hals and Pieter de Molijn.

51. Floris Soop, 1657, Getty Provenance Index. The other three are by Segers, Vonck, and "Vroom."

52. Montias rightly noted that because of these new developments it had become possible for less well-to-do people to own an original of high quality (Montias, "Influence of Economic Factors," 54).

53. Bredius, Künstler-Inventare, 229, inv. 1640, and 238, inv. 1657. On de Renialme as an art dealer for the top end of the collectors' market, see Montias, “Art Dealers." \{A good master's thesis on de Renialme's stock was written by Bram de Blécourt, University of Amsterdam, 2012.\}

54. Montias (Montias, “Art Dealers," 250) calculated the average price of works in de Renialme's inventory from 1658 at 105.8 guilders for the attributed paintings and 28.5 guilders for the paintings without attributions. Van Goyen's painting was evaluated at fortyeight guilders. Works by Steen, Bramer, Molijn, Palamedes, and others were cheaper, as were "tronies" by Rembrandt (twelve guilders), Dou (thirty guilders), Lievens (twenty guilders) and a landscape by Lievens (twenty-four guilders). Among this latter group of artists, however, there were also works between one hundred and fifteen hundred guilders (the latter the value of a Rembrandt work). The Van Goyen in the inventory of 1640, which had much lower prices overall, was estimated at only twelve guilders; in this inventory the works by Frans Hals, Miense Molenaer, and Quast had about the same value or even less.

55. See footnote 61 below.

56. Montias, Artists and Artisans in Delft, 236 (inventory of Nicolaes Gael); it is noteworthy that in this inventory there are also several copies after other masters, including Salomon van Ruysdael, Esaias van de Velde, and Pieter de Molijn, among others.

57. See n. 41 and 45 above.

58. Bredius, Künstler-Inventare, 1439 (inventory of Judith Willemsdr. van Vliet, 1650). 
59. Neil De Marchi and Hans J. Van Miegroet, "Pricing Invention: 'Originals,' 'Copies' and their Relative Value in Seventeenth-Century Netherlandish Art Markets," in Recent Contributions to the Economics of the Arts, eds. Victor Ginsburgh and Pierre-Michel Menger (Amsterdam: Elsevier Science, 1996), 54-58.

60. Bredius, Künstler-Inventare, 457-520.

61. Calculated by John Michael Montias, "Estimates of the number of Dutch Masters, Their Earnings and the Output in 1650," Leidschrift 6, no. 3 (1990), 69, cited by De Marchi and Van Miegroet, "Pricing Invention," 57.

62. I made a mistake here. There were twenty-nine works by Van Goyen in this sale, of which the average estimate is 16.6 guilders. Reindert Falkenburg pointed this out, but he made a mistake too: he missed one painting estimated at twenty-five guilders. Reindert Falkenburg, "Onweer bij Jan van Goyen: Artistieke wedijver en de markt voor het Hollandse landschap in de 17de eeuw," in "Natuur en landschap in de Nederlandse kunst 1500-1800/Nature and Landscape in Netherlandish Art 1500-1800," ed. Reindert Falkenburg et al., special issue, Nederlands Kunsthistorisch Jaarboek/Netherlands Yearbook for History of Art 48 (1997): 153n14.\}

63. Inventory of Henric Bugge van Ring, 1667 (see also n. 40: "A large Landscape by Jan van Goyen being a tavern with a coach and Hunter, done in the year 1627" \{See Sluijter, "All striving," 119\}. Unfortunately, the painting cannot be identified.

64. At the beginning of the eighteenth century, the Rotterdam doctor Bernard Mandeville, active in England (see also n. 88), noted among the factors determining the value of a work of art not only the name of the artist, the scarcity of his work, and the status of the former owner but also "Time of his Age." By this he probably meant the period of the artist's development (see De Marchi and Van Miegroet, "Art, Value," 454-55). Presumably such criteria were already valid in the seventeenth century. It is possible that by the time the inventory of Bugge van Ring's vast collection was drawn up in 1667 (clearly in the presence of the owner), the early work by Van Goyen had appreciated to a higher value than the generally more monochrome and loosely painted work from his later years.

65. Information received from Piet Bakker, based on the total number of inventories assembled by Willemijn Fock. \{The inventory with the one-hundred-guilder painting is of Jean le Pla (merchant), ELO, NA not. K. Outerman, inv. 444, deed 173, March 4, 1647. The painting is described as "a large landscape with inns"; it was by far the most expensive of the fifteen paintings valued by the expert Hendrick Uylenburg. A second painting was recorded as "a small piece with small boats," was valued at twenty-four guilders. Le Pla also owned, among others, two works by "Ruysdael" (36 and 20 guilders) and two by Isaac van Ostade (48 and 36 guilders). $\}$

66. \{Piet Bakker informed me of another four pre-1660 paintings with estimations in the total number of inventories assembled by Willemijn Fock (see n. 31), among which one is estimated at one hundred guilders (see n. 66) and the others at twenty-four, seventeen, and fifteen. The average estimation of these fourteen paintings is 24.12 guilders, but when the unusual peak of one hundred guilders is left out, the average is 18.3 guilders, instead of the 17.9-guilder average of the ten estimated paintings in the selection of 120 inventories.\}

67. On the basis of estimated paintings in a reasonably large number of inventories and other sources for the period before 1650, Alan Chong calculated an average 16.8 guilders (for 
thirty-seven works), and an average of 17 guilders (eleven works) for the period between 1650 and 1675 (Chong, "Market for Landscape," 117). \{Falkenburg criticized the fact that I used averages, which is indeed not ideal, but Falkenburg's arguments about what he perceived as Van Goyen's much lower price level, based on applying the median values from the 1647 auction in The Hague (see above, n. 60-63) are flawed. The fact that eleven of the thirty-nine paintings yielded between twenty-two and thirty-two guilders, sums that were quite rare at this huge auction, is more telling than the median (only 12.5 guilders). In the Leiden inventories (ten inventories with estimates) the median is, before 1660, fifteen guilders (average eighteen guilders); in the Montias Database (seven inventories with estimates) the median is eighteen guilders (average 29.8), and in the Getty Provenance Index (seven inventories with estimates) the median is twenty-two guilders (average 27.4). These great differences show that medians are, with such small numbers, even more problematic than averages. With regard to The Hague sale of 1647 , median values only indicate that there were a large number of paintings of lesser quality in this auctionprobably often of a smaller size; prices were connected with both size and technical and artistic quality. These lower-priced works were probably made during the 1640s when Van Goyen raised his production considerably and made many rather uninteresting works. Falkenburg, "Onweer bij Jan van Goyen," 153n14. I should also emphasize here that I calculated the estimates before 1660, which accounts the differences between my numbers and those of Chong and Montias.\}

68. Pieter Gerritsz. van Hogemade owned sixty-nine paintings (inv. Fock no. 64; ELO, NA not. K. Outermans, inv. 443, deed 121, April 23, 1652); his three works by Van Goyen were estimated at respectively thirty-three, fifteen, and another fifteen guilders. Only a shepherd and shepherdess by van den Tempel was valued higher (eighty guilders). Two pieces by Moyaert, however, were estimated together at eighteen guilders, and two by Van de Venne at fifteen guilders.

69. Montias, "Works of Art in Seventeenth-Century Amsterdam," 366. \{I wonder if Montias made a mistake here. See the Montias Database, in which we find two Van Goyens estimated for a high price: forty-four guilders in 1643 (Susanna van de Venne, who might have been related to Adriaen van de Venne, by whom she owned two paintings) and thirty guilders in 1657 (Aaltje Gerrits; appraised by Gerrit Uylenburg). The other paintings were valued at eighteen, fourteen, twelve, and five guilders respectively. If we do not count the forty-eight guilders of the painting in the inventory of De Renialme (see n. 55) the average is 20.5 guilders.

70. The average value of the thirty-six estimated pictures I found in inventories between 1660 and 1700 is 13.7 guilders. This figure, however, is inflated because there are a few highly estimated pieces in inventories from the 1660s, such as a work valued at forty-eight guilders with Nicolaes Meyer in Utrecht (1663), one at thirty-six guilders with Francois Gysels in Amsterdam (1666), and three with Gerrit Kinckhuijsen in Haarlem (1668) at twenty-five, twenty-four, and twenty guilders. Estimates of three to six guilders, however, became more and more frequent as the decades go on.

71. Published in Fock, "Kunstbezit Leiden," 32-33. \{For an image of the poster, see C. Willemijn Fock, "Art Ownership in Leiden," fig. 2.\} 
72. A work of one "Geelgefruyt"(?) is valued at 150 guilders (as much as the de Grebber), and the Hillegaert at three hundred guilders. No subject is mentioned for the latter; it was probably a large painting with many cavalrymen.

73. Miedema, Archiefbescheiden, 158.

74. Adriaan van der Willigen, Geschiedkundige aanteekeningen over Haarlemsche schilders en andere beoefenaren van de beeldende kunsten (Haarlem: Erven F. Bohn, 1866), 12, nos. 29, 32 , and 36.

75. For the Delft history painter Leonaert Bramer, who also used a rapid technique, Montias calculated an average value of only fourteen guilders. Van Goyen's reputation must have been much higher. This also shows that history paintings were not necessarily valued higher than landscapes, as has often been maintained; see John Michael Montias, "Bramer's Patrons and Clients in Delft," in Leonaert Bramer 1596-1674: Ingenious Painter and Draughtsman in Rome and Delft, ed. Jane ten Brink-Goldsmith et al., exh. cat (Zwolle and Delft: Waanders and Museum Prinsenhof, 1994), 43. Montias recorded nineteen paintings in Delft inventories.

76. On this subject, see Sluijter, "Leidse fijnschilders," 26. Joachim von Sandrart recorded that Dou charged six guilders (ein Pfund Flemsch) an hour. This seems to be an exaggeration, but it makes clear that he worked at an hourly rate and that he demanded exorbitant prices. Adriaen van der Werff, the most expensive painter of his time and a fine painter working for the elite of Europe, charged twenty-five guilders a day in the beginning of the eighteenth century \{See Marten Jan Bok, "Pricing the Unpriced: How Dutch Seventeenth-Century Painters Determined the Selling Price of Their Work," in Urban Achievement in Early Modern Europe: Golden Ages in Antwerp, Amsterdam and London, ed. Patrick O'Brian et al. (Cambridge: Cambridge University Press, 2001), 186-209; and Eric Jan Sluijter, "Determining Value on the Art Market in the Golden Age: An Introduction," in Art Market and Connoisseurship: A Closer Look at Paintings by Rembrandt, Rubens and their Contemporaries, ed. Anna Tummers and K. Jonckheere (Amsterdam: Amsterdam University Press, 2008), 7-27\}.

77. See footnote 54 above. De Renialme's inventory also contained "een vroutgen" (a woman) by Dou valued at only forty guilders, the same as the landscape by van Goyen he had in stock. In Leiden inventories, some tronies are estimated at about thirty guilders.

78. Chong, in "Market for Landscape," 117-18, calculated the average price of Poelenburch's work at thirty guilders between 1625 and 1650 (thirteen paintings), and 92.4 guilders between 1651 and 1675 (10 paintings). \{Calculations by Nicolette Sluijter-Seijffert in 2019, based on the valued paintings in Sluijter-Seijffert, "Poelenburch," app. 2 and 3, amount to 30.5 (thirteen paintings) and 119.50 guilders (sixty-eight paintings) for those two periods, respectively. It is misleading to include the period after 1660, when the value of works by Van Goyen dropped severely and those of Poelenburch rose. If we take Poelenburch's valuations before 1660, an average of sixty-seven guilders appears, against 19.2 for Van Goyen (see n. 68), which seems a more reasonable ratio: an average of three and a half times as much.\} Montias, in "Cost and value," 461, calculated that works by Avercamp, Savery, and Brueghel, on average, were four times as expensive as works by Van Goyen, Molijn, and De Momper. These painters, too, needed at least four times as much time to make a painting. In his calculations the numbers are, however, not large enough for reasonably 
trustworthy conclusions (for example, there are only two estimated works by Van Goyen from the 1650s and four from the 1660s).

79. $\{$ See Sluijter, "Determining value," 9-13.\}

80. Van de Waal, Jan van Goyen, 50-51. The payment was made by Willem II's paymaster; other payments suggest that Dirck van der Lisse, Pieter Post, and Johannes Borsman received similar commissions. The paintings are not found in inventories of the collections of the stadholders. Someone else's drawings were probably the model.

81. About this painting, see Charles Dumas, Haagse stadsgezichten 1550-1800: Topografische schilderijen van het Haags Historisch Museum (Zwolle: Waanders, 1991), 509-17.

82. For example, see Bob Haak, The Golden Age: Dutch Painting of the Seventeenth Century (New York: Harry N. Abrams, 1984), 35. Haak assumes that such a remuneration by the government had no relation to the real market value.

83. Beck, Jan van Goyen: Oeuvreverzeichnis, vol. 2, cat. no. 488. (131.5 x 252.5 cm; Heemskerck, House Marquette, private collection). \{Since 2002, the painting is owned by the Stedelijk Museum de Lakenhal, Leiden. The country seat was identified in 2015 as Oostbos, owned by Johan Sixti, who became burgomaster of The Hague in 1644 and remained a member of The Hague council until his death in 1661; his father-in-law was a friend of Constantijn Huygens. Sixti must have given Van Goyen this commission; he also might have had a hand in the commission for the large View of The Hague. The topography, with the towing path along the Vliet; the Oostbosmill on the other bank; and the Leiden Pieterskerk, the Hooglandse Kerk and the spire of the church of Voorschoten in the distance, is very precise. It seems likely that the group in the foreground depicts Sixti himself with his wife and son. The boat with a company of wealthy people, being towed by a horseman, is not a towing barge but a speelschuit, a pleasure boat, probably owned by Sixti, who had the right to use the towing path. See Piet van der Plas and Martine van der Wielen-de Goede, "Roucoop of Oostbos? Gezicht op de Vliet door Jan van Goyen," Leids Jaarboekje 107 (2015), 119-134.\}

84. Beck, Jan Van Goyen: Oeuvreverzeichnis, vol. 2, cat. nos. 292 and 973, both in Petworth House, National Trust.

85. Beck, Jan Van Goyen: Oeuvreverzeichnis, vol. 2, cat. no. 349 (Town Hall of Nijmegen; presently in Museum het Valkhof, Nijmegen) and no. 378 (Art Gallery of Toronto). The view of Nijmegen $(151 \times 255 \mathrm{~cm})$, has been owned by the city of Nijmegen since 1818; whether it was already there before that year and had been painted on commission for the city cannot be ascertained. About this work, see, among others, Edwin Buijsen, The Sketchbook of Jan van Goyen from the Bredius-Kronig Collection (The Hague: Foundation Bredius Genootschap, 1993), 167-68.

86. Although the horizons in all these works now appear to be at the same level, when one imagines the last two with a height of about $161 \mathrm{~cm}$ (assuming that they have been cropped), their compositions are not compatible with each other, nor with the views of Haarlem and Dordrecht, which correspond perfectly with each other.

87. Scarcity is also one of the elements determining value that Bernard Mandeville mentioned; see De Marchi and Van Miegroet, “Art, Value," 454-55, and also n. 65.

88. For example, Chong, "Market for Landscape," 155. Chong includes him in a list of landscape painters "highest paid in their own lifetimes." \{See also Sluijter, "Raphel' in zeeschilderen," 351\}. 
89. Karel van Mander, “Levens,” Het schilder-boeck (Haarlem, 1603-1604), fol. 238r: “. . . after his death ... sometimes even twelve times as much as when they were bought."

90. Arnold Houbraken, De groote schouburgh der Nederlantsche konstschilders en schilderessen (The Hague: 1753; first published 1718-1721), 2:131.

91. Gerard de Lairesse, Groot Schilderboek (Amsterdam, 1740; written in 1707), 1:359.

92. Crucial here are the reduction of the colors and the increasing number of gradations of one color; I prefer the word above "tonal" because the latter has so many other implications. See Wolfgang Stechow, Dutch Landscape Painting of the Seventeenth Century (London: Phaidon, 1966), 191-92n9; Stechow prefers “tonal.” See Beck, Jan van Goyen: Verzeichnis, 1:46-47 for the changes in Van Goyen's coloring over his whole career.

93. See Gifford, "Style and Technique." \{And Gifford, "Jan van Goyen.”\}.

94. About the elaborate method of working color-by-color, using several palettes, see Ernst van de Wetering, "De paletten van Rembrandt en Jozef Israels, een onderzoek naar de relatie tussen stijl en schildertechniek," Oud Holland 107 (1993): 140-47.

95. Jonathan Israel, in a lecture delivered in Leiden on March 28, 1996, argued that an economic recession at the end of the 1620 s and the 1630 s and the increasing price of pigments in this period-vermilion, for example-must have been important reasons to produce inexpensive paintings with fewer, cheaper pigments. Naturally this may have played a role, but we should realize that many painters did not adopt this manner; it is also misleading to say that during the 1640s everyone suddenly started to paint colorfully and with detail again, as Israel suggested (see n. 16). \{Israel's lecture was published as Jonathan I. Israel, "Adjusting to Hard Times: Dutch Art During its Period of Crisis and Restructuring (c. 16211645)," Art History 20 (1997), 449-76; his notion of economic recession during this period is, however, highly disputable. Moreover, in light of the enormous growth of the number of painters and the production of paintings in this same period, his thesis seems untenable.\}

96. Hoogstraten, Inleyding, 237. According to Emmens, van Hoogstraten uses this (probably imaginary) contest as a "parable" to show three hierarchically distinguished ways of painting within art theory. They can be related to the concepts of "idea" (Porcellis), fortuna (chance; Van Goyen), and usus (practice; Knibbergen); see Jan A. Emmens, Rembrandt en de regels van de kunst (Amsterdam: C.A. van Oorschot, 1979), 16668; and Ernst van de Wetering, "Leidse schilders achter de ezel," in Geschildert tot Leyden anno 1626, ed. Maarten Wurfbain et al., exh. cat. (Leiden: Stedelijk Museum de Lakenhal, 1976), 21-24. Nevertheless, this text gives a good impression of Van Goyen's manner of working. Hoogstraten exaggerated the emphasis on "chaos"-chance-to make his argument stronger. See also n. 98.

97. Jacques de Ville's scornful remark (in a pamphlet of 1628) about people who "only gape at the manner" (handeling) makes clear that, to his chagrin, many connoisseurs value precisely the peinture. See Emmens, Rembrandt en de regels van de kunst, 121. \{On de Ville's text, see Eric Jan Sluijter, Rembrandt and the Female Nude (Amsterdam: Amsterdam University Press, 2006), 209-211.\}

98. Cited in Ernst van de Wetering, "Rembrandt's Method: Technique in the Service of Illusion," in Rembrandt: The Master and His Workshop; Paintings, ed. Christopher Brown, Jan Kelch, and Pieter van Thiel, exh. cat. (New Haven and London: Yale University Press 
and National Gallery, 1991), 16 and n. 9, citing Pierre Le Brun, "Recueil des essaies des merveilles de la peinture" (1635), in Original Treatises on the Art of Painting, ed. Mary P. (Merrifield: Dover Publications, 1967), 2:766-848. This appreciation, which can also be connected with the notion of "sprezzatura," started in relation to sixteenth-century Italian painting (especially Titian's "rough" style), and has been related to Rembrandt's endeavours (see van de Wetering, "Rembrandt's Method," 16-17). Van Goyen, however, appears to be striving to acquire this kind of appreciation with another type of art and through his seemingly "casual," loose, and rapid manner of painting. "Sprezzatura," a concept that Baldassare Castiglione explained by comparing the posture of the courtier with the seemingly casual brushstroke of the painter, was translated as lossigheydt (looseness), the same word Philips Angel used for a rapid, fluid way of painting (see n. 15).

99. An example: “. . . ein blühende Produktion von Fluss- und Flachlandansichten in einem grüngelben, blaugrauen oder wohl auch braunen Ton, einfache Motive, in denen die typisch holländische, mit Dunst durchtränkte Atmosphäre zur Geltung komt.” Laurens J. Bol, Holländische Maler des 17. Jarhunderts nahe der großen Meistern (München: Klinkhardt \& Biermann, 1982), 165. Also characteristic is Beck's description of Van Goyen's style in 1640-1645, which he calls "the period of absolute tonality": "Die feuchte, dustgetränkte Meeresluft verdrängt die Lokalfarben aus der Landschaftsszenerie zugunsten einer malerischen, tonigen Färbung; einzelheiten verlieren sich, verschimmen in zarten nebeligen Dunst der Ferne, die sich mit der Atmosphäre verbindet." (Beck, Jan van Goyen: Oeuvreverzeichnis, 1:46).

100. It is interesting that Van de Waal, usually an acute observer, was drawn so much to this idea that he wrote: "The inexpressible delicate light over our Dutch waters, the refined silvery tones and grays of our humid atmosphere, have been his subject during his whole life" (Van de Waal, Jan van Goyen, 20). In the first place, there are not so many grays and silver tones in Van Goyen's landscapes-brown and yellow tones dominate-and second, these are in reality not at all characteristic for the Dutch water landscape unless the weather is distinctly foggy, with limited sight and an overcast sky. Only then might one say that "from some distance the separate colors, to a great extent, lose their own character to sink into an indefinite silver-gray monochromy" (Van de Waal, Jan van Goyen, 31). Nonetheless, Van de Waal is, of course, absolutely right that Van Goyen was able to suggest an inexpressibly delicate light in a breathtaking way.

101. Many authors see a misty atmosphere in Van Goyen's paintings, but there is never any discernable fogginess in his works. The sentence with which Van de Waal finishes his book- "His art knows no doubt other than that of the mist above the water and no delight other than the triumphing light"-is splendid, but only the second part of the sentence characterizes Van Goyen's work (Van de Waal, Jan van Goyen, 60).

102. See Sluijter-Seijffert, “Poelenburch,” 85. \{Sluijter-Seijffert, Poelenburch: Paintings, 103\}.

103. Van de Waal, Jan van Goyen, 59.

104. Bredius, "Capelle," nos. 154 and 155: “Twee grauwe lantschapjes (two grisaille landscapes) van Jan van Goyen." See also, among others, the inventory of Jan Miense Molenaer from 1668: “een graeuwtje van (a grisaille by) Jan van Goyen” (Bredius, Künstler-Inventare, 3), and "een graeuwtje" in the inventory Cornelis Roelandz de Vries 1682 (Getty Provenance Index). 
105. See Beck, Jan van Goyen: Oeuvreverzeichnis, 1:47 and vol. 2, nos. 245-71; three are dated 1650 and twenty 1651; they all have more or less the same size (c. $25 \mathrm{x} 40 \mathrm{~cm})$. Why this sudden outpouring of works in oil on paper? Since they show a great variety of types popular in different periods of his career (for example, dunes he made in the late 1620s and early 1630s), they might belong together as a series made on commission. Three pairs are or were still together; see Beck, Jan van Goyen: Oeuvreverzeichnis, nos. 248 and 249, 254, and 255.

106. Peter Sutton, "Introduction," in Masters of 17th-Century Dutch Landscape Painting, 6, with reference to a conference paper presented by Melanie Gifford in 1983 (see also n. 108).

107. David Bomford, "Techniques of the early Dutch Landscape Painters," in Dutch Landscape: The Early Years; Haarlem and Amsterdam 1590-1650, ed. Christopher Brown, exh. cat. (London: National Gallery Publications, 1986), 55. Melanie Gifford had earlier indicated that this Haarlem blue must relate to smalt, but she supposed that Van Goyen used an almost colorless smalt on purpose (Gifford, "Style and Technique," 145, with reference to her paper from 1983; see n. 107).

108. \{Gifford, "Jan van Goyen," 78.

109. A long training, especially when this was undertaken with many masters for short periods, was expensive; see Ronald de Jager, "Meester, leerjongen, leertijd: Een analyse van zeventiende-eeuwse Noord-Nederlandse leerlingcontracten van kunstschilder, goud- en zilversmeden," Oud Holland 104 (1990): 75.

110. De Jager, "Meester, leerjongen," 70. From van Mander's biographies Miedema concluded that the average age was twelve to fourteen years old; in the contracts that de Jager examined, the age at which training began varies from twelve to sixteen.

111. Orlers, Beschrijvinge, 373.

112. Orlers explicitly emphasized "de aerdicheyt van Beelden" (the amusingness of figures). In the inventory of Jan Orlers's own painting collection we find three paintings - two by Van Goyen's first master Coenraet van Schilperoort and one by the Delft painter Pieter Staelwith the mention of "met Beelden van (with figures by) Mr Jan van Goyen"; see Maarten Wurfbain et al., Geschildert tot Leyden anno 1626, exh. cat. (Leiden: Stedelijk Museum de Lakenhal, 1976), 17. In Cornelis Borsman's inventory from The Hague, "a large landscape by van Knipbergen with figures by Jan van Goyen" is recorded; Bredius, Künstler-Inventare, 2141-44 (1658) (see also n. 47). The fact that this was mentioned in inventories indicates that it was not only much appreciated and probably raised the value but also that Van Goyen must often have painted figures in the works of colleagues.

113. Van Mander, Schilder-boeck, "Grondt," fol. 36r.

114. In 1641, Angel still emphasizes the "aerdich-vercierende Rijckelijckheydt" (pleasant embellishment of a rich variety). Angel, Lof der schilder-konst, 39.

115. Van de Waal, in Jan van Goyen, 13-14, refers to these lines in Van Mander's text in connection with Van Goyen's early work.

116. Van Mander, Schilder-boeck, "Grondt," fol. 38r. Peter Sutton, in his excellent survey of landscape painting, noticed that this passage calls to mind the works that Van Goyen, Salomon van Ruysdael, and Molijn would paint in the 1620s (Sutton, "Introduction," 10).

117. These words from Spiegel relate to his rejection of the use of classical mythology in poetry, as part of his struggle for an indigenous culture and language; Hendrick Laurenszn 
Spiegel, Hart-spieghel (Amsterdam, 1614), 6; see also Marijke Spies, “'Poëetsche fabrijcken' en andere allegorieën eind 16de begin 17de eeuw,” Oud Holland 105 (1991): 238-39. However, this passage contains elements that also seem to reflect new directions in visual art. The splendid lines that directly follow seem also to be echoed in painting: "Parnassus is too far, there is no Helikon here, / But dunes, woods and brooks and sky, under the same sun. / Therefore we open-heartedly hold dear with helpless love / The goddesses of this country's salubrious brooks, fields and streams." See also Eric Jan Sluijter, "De 'heydensche fabulen' in de Noord-nederlandse schilderkunst, circa 1590-1670" (PhD diss. Leiden University, 1986), 335-36). On the relationship between literature and visual art in this period of the rise of the native landscape, see Huigen Leeflang's important article "Het aardse paradijs: Het Haarlemse landschap in 16de en 17de-eeuwse literatuur en beeldende kunst," in De trots van Haarlem: Promotie van een stad in kunst en historie, ed. Koos LevyVan Halm et al., exh. cat. (Gent: Snouck-Ducaju, 1995), 116-34, esp. 119-24). \{See also his magisterial article "Dutch Landscape: The Urban View: Haarlem and Its Environs in Literature and Art, 15th-17th century," in Falkenburg et al., ed., "Natuur en landschap": $52-115$.

118. Van Mander, Schilder-boeck, "Grondt," fol. 38r. See also the version in prose in his biography of Ludius, "Leven," fol. 87v/88r, derived from Pliny the Elder, Naturalis Historia 15:115-17; see Hessel Miedema, ed., Karel van Mander: Het leven der oude antijcke doorluchtighe schilders (Amsterdam: University of Amsterdam, 1981), at fol. 87v.

119. Similar to the numerous comparisons of history painters with Apelles or Zeuxis, or Dou as "the Dutch Parrhasius" (Sluijter, Lof der schilderkunst, 19-20). See also Reznicek's suggestion, about Paulus Potter as an "alter Pausias": E. K. J. Reznicek, "Het leerdicht van Karel van Mander en de acribie van Hessel Miedema," Oud Holland 89 (1975): 121.

120. Van Goyen's first teacher, Coenraet van Schilperoort, with whom he probably collaborated later (see n. 113), had in his large library (see Bredius, Künstler-Inventare, 557-60) a copy of Van Mander's Schilder-boeck and perhaps also Pliny the Elder's Naturalis Historia (“de bijbel der natuyr" might refer to Pliny's book). These kinds of anecdotes were probably well known to these painters.

121. On important print series with such motifs, such as the well-known series Plaisante Plaetsen (Pleasant Places) by Claes Janszn. Visscher from about 1611-14, see Huigen Leeflang, "Het landschap in boek en prent: Perceptie en interpretatie van vroeg zeventiendeeeuwse Nederlandse landschapsprenten," in Nederland naar 't leven: Landschapsprenten uit de Gouden Eeuw, ed. Boudewijn Bakker and Huigen Leeflang, exh. cat. (Zwolle and Amsterdam: Waanders and Museum het Rembrandthuis 1993), 18-32; and Boudewijn Bakker, "Levenspelgrimage of vrome wandeling? Claes Janszoon Visscher en zijn serie Plaisante Plaetsen," Oud Holland 107 (1993): 97-116. See also Jan G. C. A. Briels, Vlaamse schilders in de Noordelijke Nederlanden in het begin van de Gouden Eeuw (Haarlem: Becht, 1987), 182-83 and 367-70, about the recreational appreciation of the countryside as a projection of the town dweller.

122. Traditionally negative elements, such as a defecating or urinating man, are only known from two early works (Beck, Jan van Goyen: Oeuvreverzeichnis, vol. 2, cat. nos. 6 and 35).

123. See De Marchi and Van Miegroet, "Art, Value," 458: "Established painters of some reputation will feel more at ease in treating the market as an experimental forum to try out 
new ideas and products than will those just beginning or lacking a very distinct ability.” This statement seems to apply here.

124. See Stechow, Dutch Landscape, 23-26; and Sutton, "Introduction," 35. Given the numerous paintings that have been lost during the centuries, one should be cautious of considering a few specific paintings as crucial "cornerstones" in the "evolution" of the landscape, as Stechow did.

125. The fact that Pieter de Neyn concentrated on battle scenes-one of Esaias van de Velde's most successful specialties-seems to indicate a kind of dividing of the field; Van Goyen kept well away from such subjects.

126. This should not be considered a general tendency: in this same period painters like Poelenburch and Dou moved in an opposite direction (see also n. 16 and 96).

127. I suppose they give a reasonably truthful image of the farmhouses that were situated on this barren land.

128. The popular image of country life in the literature of that time consisted of elements of the Horatian beatus ille fused with ethical notions based on neostoicism. The poet Hendrik Laurensz. Spiegel was a preeminent spokesperson of such thoughts, but they played an important role in the work of many other authors as well; see Mieke Smits-Veldt, Samuel Coster, ethicus-didacticus: Een onderzoek naar dramatische opzet en morele instructie van Ithys, Polyxena, en Iphigenia (Groningen: Wolters-Noordhoff/Forsten, 1986), 193-201. See also Sutton, "Introduction," 36.

129. See the splendid essay on this subject by Boudewijn Bakker in Oud Holland: Bakker, "Levenspelgrimage of vrome wandeling?"

130. See Leeflang, "Aardse paradijs," 120 and 123 \{and Leeflang, "The Urban View”\}; see also Bakker and Leeflang, eds., Nederland naar't leven, 76-77, no. 24, in which the view of a dune (and the tower of Zandvoort) is connected in the accompanying verse to an emphatically amorous-pastoral atmosphere.

131. This low viewpoint had been introduced more than a decade earlier in drawings and prints by Claes Janszn. Visscher, Esaias van de Velde, Jan van de Velde II, and Willem Buytewech, while Porcellis started to use it in the middle of the 1620s in seascapes. After the mid-1620s, however, we see how some young painters, among them Pieter de Molijn and Salomon van Ruysdael, begin almost at the same time to experiment with it in landscape paintings. The extreme low vantage point of Arent Arentsz. Cabel's earlier works is remarkable in this aspect.

132. For a convincing argument about the importance attached to the depiction of landscapes "after life" in this period:, see Boudewijn Bakker, "Nederland naar 't leven: Een inleiding," in Bakker and Leeflang, Nederland naar 't leven, 6-17.

133. Especially by van de Waal, Jan van Goyen; Stechow, Dutch Landscape; and Beck, Jan van Goyen: Oeuvreverzeichnis. The overview of the different types, as concisely sketched out below, would be impossible without the excellent catalogue by Hans-Ulrich Beck and his introductory survey (Beck, Jan van Goyen: Oeuvreverzeichnis, 1:42-50).

134. Montias, "Influence of Economic Factors," and De Marchi and Van Miegroet, "Art, Value” in particular point out that in a market with much competition, strategies of differentiation and innovative behavior were necessary to become a successful artist (see also n. 124). On followers, see n. 144 . 
135. Valuable papers on the development of river views with and without distinctive architectural motifs have been written by Sabine Giepmans and John Veerman for the seminar I taught at Leiden University in the fall of 1995 (see Postscript).

136. The origin and development of the beach view, especially the view of Scheveningen, were examined in a paper by Marthe de Vet, Leiden University seminar, 1995.

137. See Beck, Jan van Goyen: Oeuvreverzeichnis, 1:29 (document about the sale in 1625 of a house at Pieterskerkstraat in Leiden to Jan Porcellis, which his widow sells again to the seascape painter Hendrick Anthonisz).

138. Houbraken praises especially his "calm water views with market ships, and fishing boats, and a small church, or some familiar village at the horizon." Houbraken, Groote schouburg, $1: 171$.

139. See n. 85 and 86.

140. This was well analyzed in the papers by Adriaan Waiboer, Sander Paarlberg, and Albert Smit about the views of, respectively, Rhenen, Dordrecht, and Nijmegen, Leiden University seminar, 1995.

141. A good analysis of van Goyen's “winters” was written by Ed Romein, Leiden University Seminar, 1995.

142. \{See Reindert Falkenburg, “Onweer bij Jan van Goyen,” 116-61 (Zwolle: Waanders, 1998). In this article Falkenburg takes issue with my theses regarding Van Goyen's innovations in types of landscape as an artistic and economic strategy; see my "postscript" and n. 15; see also n. 68.\}

143. "Zag iemand stiller weder? / De vlaggens hangen neder, / Het zeil en doet geen boet, / En al den voortgang komt ons van den tragen vloed." See Karel Porteman, "Zeventiende-eeuwse dichters in last," in Brekende spiegels: Beeldveranderingen in de Nederlandse literatuur, ed. Dirk de Geest and Marc van Vaeck (Leuven: Peeters, 1992), 53-54. This experience of a calm leads the poet toward a reflection on unfulfilled yearnings for God. Porteman stated that it is an attractive idea to connect this approach to nature to the landscape painting of that time. I am grateful to Huigen Leeflang, who drew my attention to this article.

144. See Hans-Ulrich Beck, Künstler um Jan van Goyen: Maler und Zeichner (Doornspijk: Davaco, 1991). For example: Cornelis Beelt (beach views), Cornelis de Bie (beach views), Jan Coelenbier (river views, with architecture), Anth. van der Croos (prospects with cities), Jheronimus van Diest (calm water), Frans de Hulst (dunes and river views with architecture), Wouter Knijff (river views with architecture), Willem Kool (beach views and winters), monogr. PHB (river views), Jacob van Moscher (dunes), Joh. Schoeff (river views, dunes), and Joos de Volder (dunes).

145. Van Hoogstraten, Inleyding, 11-12.

146. Wilhelm Martin, De Hollandse schilderkunst in de zeventiende eeuw (Amsterdam: Meulenhoff, 1936-1936), 1:277.

147. Edwin Buijsen, "De schetsboeken van Jan van Goyen," 22-37; Reindert L. Falkenburg, "'Schilderachtig weer' bij Jan van Goyen," 60-69; E. Melanie Gifford, "Jan van Goyen en de techniek van het naturalistische landschap," 70-79; Eric Jan Sluijter, "Jan van Goyen als marktleider, virtuoos en vernieuwer," 38-59. The catalogue also contains a biographical survey by Sabine Craft-Giepmans (8-9), and an introduction by Christiaan Vogelaar (1021). 
148. Especially those by Sabine Craft-Giepmans, Sander Paarlberg, Ed Romein, Marthe de Vet, and Adriaan Waiboer; see n. 136, 137, 141, and 142.

149. About seventeenth-century ways of beholding things represented in a painting as a "virtual reality," see Thijs Weststeijn, The Visible World: Samuel van Hoogstraten's Art Theory and the Legitimation of Painting in the Dutch Golden Age (Amsterdam: Amsterdam University Press, 2008), chapter 3; and Sluijter, Rembrandt and the Female Nude, 151-53, 312-16.

150. Falkenburg, "Onweer bij Jan van Goyen" (see n. 68 and 143). Falkenburg is skeptical about the idea that Van Goyen was consciously innovating in style and types of landscapes as a market strategy; he considers this a projection of modern theoretical models. Indeed, Van Goyen would not have thought in terms of "market strategy" and "product innovation." But there are enough sources (and the paintings themselves) that demonstrate that, for example, notions of process and product innovation and differentiation are relevant for this period of explosive growth in the number of painters and the production of paintings. Radical changes in supply and demand and the manner of marketing are evident. Artists showed strong awareness of the necessity of artistic and economic competition as motives for innovation in order to keep alive the interest of their audiences (see, for example, Sluijter, "Brabant Rubbish"; and Sluijter, Rembrandt's Rivals, 16-22). This is true even if the artists' innovations were not always the result of a conscious "strategy" but were instead actions by an aspiring painter to accommodate to circumstances. Falkenburg doubts that landscape types (dunescapes, riverscapes, beaches, panorama's) were distinguished; he considers this a modern categorization. However, the fact that huge numbers of a certain type were produced over a few years and then stopped-and that certain followers specialized in dunes, or river scenes, or beach scenes, and so on-is the best proof that these were seen as different categories. That we do not find such categories clearly defined in inventories does not say much; these were drawn up for specific purposes. An inventive painter like Van Goyen realized when the interest in dunes or beaches or riverscapes waned among his clients, because they owned already one or two, or when a certain type was imitated by many others, which would have pushed down prices. Falkenburg's argument also seems to imply that such landscapes were just compositions, for which the specific subjects did not matter much. But it would have been entirely different to imagine oneself as if walking on a beach, sailing on a river, strolling in the dunes, or looking out over a panorama. Falkenburg's discussion of the depiction of thunderstorms and the importance of artistic competition is highly stimulating. 